\title{
Chemical characteristics of size-resolved atmospheric aerosols in Iasi, north-eastern Romania: nitrogen-containing inorganic compounds control aerosol chemistry in the area
}

\author{
Alina Giorgiana Galon-Negru ${ }^{1}$, Romeo Iulian Olariu ${ }^{1,2}$, and Cecilia Arsene ${ }^{1,2}$ \\ 1 “Alexandru Ioan Cuza” University of Iasi, Faculty of Chemistry, Department of Chemistry, 11 Carol I, 700506 Iasi, Romania \\ 2"Alexandru Ioan Cuza" University of Iasi, Integrated Centre of Environmental Science Studies in the North Eastern Region, \\ 11 Carol I, Iasi 700506, Romania
}

Correspondence: Cecilia Arsene (carsene@uaic.ro)

Received: 2 November 2017 - Discussion started: 17 November 2017

Revised: 27 February 2018 - Accepted: 14 March 2018 - Published: 26 April 2018

\begin{abstract}
This study assesses the effects of particle size and season on the content of the major inorganic and organic aerosol ionic components in the Iasi urban area, north-eastern Romania. Continuous measurements were carried out over 2016 using a cascade Dekati low-pressure impactor (DLPI) performing aerosol size classification in 13 specific fractions over the $0.0276-9.94 \mu \mathrm{m}$ size range. Fine-particulate $\mathrm{Cl}^{-}, \mathrm{NO}_{3}^{-}, \mathrm{NH}_{4}^{+}$, and $\mathrm{K}^{+}$exhibited clear minima during the warm season and clear maxima over the cold season, mainly due to trends in emission sources, changes in the mixing layer depth and specific meteorological conditions. Fine-particulate $\mathrm{SO}_{4}^{2-}$ did not show much variation with respect to seasons. Particulate $\mathrm{NH}_{4}^{+}$and $\mathrm{NO}_{3}^{-}$ions were identified as critical parameters controlling aerosol chemistry in the area, and their measured concentrations in fine-mode $\left(\mathrm{PM}_{2.5}\right)$ aerosols were found to be in reasonable good agreement with modelled values for winter but not for summer. The likely reason is that $\mathrm{NH}_{4} \mathrm{NO}_{3}$ aerosols are lost due to volatility over the warm season. We found that $\mathrm{NH}_{4}^{+}$in $\mathrm{PM}_{2.5}$ is primarily associated with $\mathrm{SO}_{4}^{2-}$ and $\mathrm{NO}_{3}^{-}$but not with $\mathrm{Cl}^{-}$. Actually, indirect ISORROPIA-II estimations showed that the atmosphere in the Iasi area might be ammonia rich during both the cold and warm seasons, enabling enough $\mathrm{NH}_{3}$ to be present to neutralize $\mathrm{H}_{2} \mathrm{SO}_{4}, \mathrm{HNO}_{3}$, and $\mathrm{HCl}$ acidic components and to generate fine-particulate ammonium salts, in the form of $\left(\mathrm{NH}_{4}\right)_{2} \mathrm{SO}_{4}, \mathrm{NH}_{4} \mathrm{NO}_{3}$, and $\mathrm{NH}_{4} \mathrm{Cl}$. ISORROPIA-II runs allowed us to estimate that over the warm season $\sim 35 \%$ of the total analysed samples had very strongly acidic $\mathrm{pH}(0-$ 3 ), a fraction that rose to $\sim 43 \%$ over the cold season. More-
\end{abstract}

over, while in the cold season the acidity is mainly accounted for by inorganic acids, in the warm ones there is an important contribution by other compounds, possibly organic. Indeed, changes in aerosol acidity would most likely impact the gasparticle partitioning of semi-volatile organic acids. Overall, we estimate that within the aerosol mass concentration the ionic mass brings a contribution as high as $40.6 \%$, with the rest still being unaccounted for.

\section{Introduction}

Despite dramatic progress made to improve air quality, global air pollution continues to harm people's health and the environment. The problem of aerosols or particulate matter (PM) is still a great concern (Olariu et al., 2015) in Europe and many other areas in the world (e.g. China, India, USA). Atmospheric aerosols, described as complex mixtures of liquid and/or solid particles suspended in a gas (Olariu et al., 2015), mainly originate from anthropogenic and natural sources (Querol et al., 2004). Fine $\mathrm{PM}_{2.5}$ particles (airborne particles with an equivalent aerodynamic diameter $<2.5 \mu \mathrm{m}$ ) are air pollutants with significant effects on human health (Pope et al., 2004; Dominici et al., 2006; WHO, 2006a; Directive 2008/50/EC, 2008; Sicard et al., 2011; Ostro et al., 2014) as well as air quality (Directive 2008/50/EC, 2008; Freney et al., 2014), visibility (Directive 2008/50/EC, 2008; Tsai and Cheng, 1999), ecosystems, weather, and climate (Ramanathan et al., 2001; Directive 2008/50/EC, 2008; 
IPCC, 2013). Aerosols are also known to play a significant role within the chemistry of the atmosphere (Prinn, 2003), acting as surfaces for heterogeneous chemical reactions (Ravishankara, 1997).

Safety threshold values for both $\mathrm{PM}_{2.5}$ (10 or $17 \mu \mathrm{g} \mathrm{m}^{-3}$ air, as annual mean) and $\mathrm{PM}_{10}$ (airborne particles with an equivalent aerodynamic diameter $<10 \mu \mathrm{m} ; 20$ or $28 \mu \mathrm{g} \mathrm{m}^{-3}$ air, as annual mean) are addressed by the WHO (2006b) or by the 2008/50/EC Directive (2008) on ambient air quality and cleaner air for Europe. With regard to the $\mathrm{PM}_{2.5}$ fraction, the EEA Report (2015) indicates that in 2013 the European Union daily limit values for $\mathrm{PM}_{10}$ and $\mathrm{PM}_{2.5}$ were exceeded in, respectively, 22 and 7 out of the 28 European Union member states. However, a decreasing trend was observed when compared with the WHO report data (2006b). Moreover, on a global scale the $\mathrm{PM}_{2.5}$ exposure leads to about 3.3 million premature deaths per year (predominantly in Asia), a figure that could double by 2050 (Lelieveld et al., 2015). Indeed, PM air pollution imparts a tremendous burden to the global public health because it ranks as the 13th leading cause of mortality (Brook, 2008).

Up to now the chemical composition of atmospheric aerosols has been reported for various urban European sites (Bardouki et al., 2003; Hitzenberger et al., 2006; Tursic et al., 2006; Gerasopoulos et al., 2007; Schwarz et al., 2012; Laongsri and Harrison, 2013; Wonaschutz et al., 2015; Sandrini et al., 2016), but such information is very scarce in eastern Europe (Arsene et al., 2011). Sulfate $\left(\mathrm{SO}_{4}^{2-}\right)$, nitrate $\left(\mathrm{NO}_{3}^{-}\right)$, and ammonium $\left(\mathrm{NH}_{4}^{+}\right)$ions, which are major inorganic particle constituents (Wang et al., 2005; Bressi et al., 2013; Hasheminassab et al., 2014; Voutsa et al., 2014), are mainly secondary species formed in the atmosphere by chemical reactions of their precursor gases and by physical processes (nucleation, condensation, etc.) (Aksoyoglu et al., 2017). Ammonium aerosols, with an atmospheric lifetime of 1-15 days, have a clear tendency to deposit at large distances from their emission sources (Aneja et al., 2000) and seem to play a very important role in atmospheric chemistry. In urban air, the abundance of $\mathrm{NO}_{3}^{-}$on fine particles seems to mainly depend on the reaction between $\mathrm{HNO}_{3}$ and $\mathrm{NH}_{3}$ (Stockwell et al., 2000). On a global scale, $\mathrm{HNO}_{3}$ heterogeneous reactions on mineral dust and sea salt particles might be the predominant source of particulate $\mathrm{NO}_{3}^{-}$(Athanasopoulou et al., 2008; Karydis et al., 2011). The human health effects of atmospheric ammonia, primarily exerted through particulate $\mathrm{NH}_{4} \mathrm{NO}_{3}$, are gradually acquiring importance compared to $\mathrm{NO}_{x}$ emissions (Sutton et al., 2011).

Relative humidity (RH; Jang et al., 2002) and gas-particle partitioning processes of semi-volatile species $\left(\mathrm{NH}_{3}, \mathrm{HNO}_{3}\right.$, $\mathrm{HCl}$, and some organic acids) affect the hydronium ion $\left(\mathrm{H}_{3} \mathrm{O}^{+}\right)$concentrations (Keene et al., 2004; Guo et al., 2016) as well as aerosol formation and chemical composition. Aerosol acidity is often estimated with ion balance methods (Trebs et al., 2005; Metzger et al., 2006; Arsene et al., 2011), phase partitioning (Meskhidze et al., 2003; Keene et al., 2004), and thermodynamic equilibrium models, e.g. E-AIM (Clegg et al., 1998; Wexler and Clegg, 2002) or ISORROPIA-II (Nenes et al., 1999; Fountoukis and Nenes, 2007; Hennigan et al., 2015; Guo et al., 2015, 2016; Fang et al., 2017). Acidity might influence transition metals' solubility and enhance aerosol toxicity and the delivery of nutrients by atmospheric deposition in marine areas (Meskhidze et al., 2003; Fang et al., 2017).

Unfortunately, the aerosols' role in the global atmospheric system is not yet sufficiently understood. The main related challenges are the occurrence of multiple sources (e.g. soil erosion, sea spray, biogenic emissions, volcano eruptions, soot from combustion, condensation of precursor gases) and the complexity of interactions with other atmospheric constituents (Zhang et al., 2015). Today, sources, distribution, and behaviour of natural and anthropogenic aerosols are still a matter of debate, exacerbated by the scarcity of aerosolrelated work for eastern European Union countries (EEA Report, 2015) but also by the existing discrepancies between models and field measurements. The main uncertainties are related to secondary inorganic aerosols that control the availability of atmospheric sulfuric acid $\left(\mathrm{H}_{2} \mathrm{SO}_{4}\right)$, nitric acid $\left(\mathrm{HNO}_{3}\right)$, and ammonia $\left(\mathrm{NH}_{3}\right)$ (Ianniello et al., 2011). The existing knowledge gaps bring high uncertainty in the estimated radiative forcing, although they do not impair the conclusion that warming of the climate system is unequivocal (IPCC, 2013).

Despite a growing international recognition of the importance of air pollution and air quality problems, there is a definite need to assess air pollution patterns in Romania. The existing data for north-eastern Romania concern the chemical characteristics of ambient air pollutants such as the watersoluble ionic constituents of aerosols (Arsene et al., 2011) and rainwater (Arsene et al., 2007). Recent work performed by Arsene's group in the field of atmospheric chemistry has clearly shown that, in the Iasi urban environment (northeastern Romania), $\sim 59 \%$ of the total aerosol mass concentration is still unaccounted for. The present work reports, for the first time, detailed information on the chemical composition and seasonal variation in size-segregated, water-soluble ions in aerosol samples collected throughout 2016 in the Iasi urban area, also taking into account the potential ongoing chemistry and the contributions of critical driving forces such as meteorological factors ( $\mathrm{RH}$, temperature), mixing layer depth, and emission source intensity. As a first attempt to assess particle acidity in the area, the present work highlights the existence of significant aerosol fractions characterized by $\mathrm{pH}$ values in the very strong acidity range ( $0-3 \mathrm{pH}$ units), with potentially important implications for acid rain. Moreover, the potential importance of gaseous precursors (e.g. $\mathrm{NH}_{3}, \mathrm{HNO}_{3}, \mathrm{HCl}$ ) in secondary inorganic $\mathrm{PM}$ is also discussed. 


\section{Experiment}

\subsection{Measurement site}

Measurements were performed in Iasi, north-eastern Romania, at the Air Quality Monitoring Station (AMOS, $47^{\circ} 9^{\prime} \mathrm{N}$ latitude and $27^{\circ} 35^{\prime} \mathrm{E}$ longitude) of the Integrated Centre of Environmental Science Studies in the North-Eastern Development Region, "Alexandru Ioan Cuza" University of Iasi, CERNESIM-UAIC, Romania. AMOS is located north-east from the city centre, on the rooftop of the highest university building ( $\sim 35 \mathrm{~m}$ above the ground level), in a totally open area that characterizes the site as an urban receptor point most probably influenced by well-mixed air masses. A comprehensive demo-geographical characterization of Iasi is described in detail by Arsene et al. (2007, 2011). However, according to a more recent estimate of the Romanian National Institute of Statistics, in 2016 the population in Iasi reached about 362142 inhabitants (Ichim et al., 2016).

\subsection{Field measurements}

Size-resolved atmospheric aerosols were collected on ungreased aluminium filters ( $25 \mathrm{~mm}$ diameter) using a cascade Dekati low-pressure impactor (DLPI) operating at a flow rate of $29.85 \mathrm{~L} \mathrm{~min}^{-1}$. Similar devices have been successfully used in other studies (Kocak et al., 2007; Wonaschutz et al., 2015). The DLPI unit performs aerosol size classification in 13 specific fractions (with size cuts at $0.0276,0.0556$, $0.0945,0.155,0.260,0.381,0.612,0.946,1.60,2.39,3.99$, 6.58 , and $9.94 \mu \mathrm{m}$ at $50 \%$ calibrated aerodynamic cut-point diameters and at $21.7^{\circ} \mathrm{C}$, inlet pressure $1013.3 \mathrm{mbar}$, outlet pressure $100 \mathrm{mbar}$, and $29.85 \mathrm{~L} \mathrm{~min}^{-1}$ flow rate). Sampling performance of the DLPI unit was verified through comparison with simultaneous measurements performed with a stacked filter unit (SFU) system previously used by Arsene et al. (2011). Before each reuse the sampler's components were cleaned with ultra-pure water and methanol. Dispensable polyethylene gloves were always used to avoid hand contact with sampler's components, which were assembled and disassembled in a Labgard Class II Biological Safety Cabinet, NuAire. The DLPI sampler was transported to and from the field in tightened polyethylene bags.

Sampling was performed in 2016 twice a week, on the weekend and working days, for a total of 84 sampling events (41 during the cold season from October to March, and 43 during the warm season from April to September), generating 1092 size-resolved aerosol samples. Sampling took place on a $36 \mathrm{~h}$ basis, with each sampling event starting at 18:00 local time. An average volume of $64.33 \pm 0.85 \mathrm{~m}^{3}$ per sampling was collected. At least two field blanks (consisting of a loaded sampler taken to and from the field but never removed from its tightened bag) were generated and simultaneously analysed together with the laboratory blanks, in or- der to assess possible contamination during sampler loading, transport, or analysis.

Meteorological parameters including atmospheric temperature, $\mathrm{RH}$, wind speed, wind direction, and global radiation were provided by a Hawk GSM-240 weather station, running at the AMOS site. Information about the mixing layer depth (atmospheric boundary layer) and its ability to dilute atmospheric pollutants at the investigated site was obtained from the NOAA Air Resources Laboratory (ARL) website (Stein et al., 2015; Rolph et al., 2017).

\subsection{Sample analyses}

Aerosol masses for both the $\mathrm{PM}_{2.5}$ and $\mathrm{PM}_{10}$ fractions were gravimetrically determined with a Sartorius microbalance (MSU2.7S-000-DF, $\pm 0.2 \mu \mathrm{g}$ sensitivity) by weighing aluminium filters before and after sampling. Before weighing, filters stored in petri dishes were kept for at least 3 days in a conditioned room at $40 \pm 2 \% \mathrm{RH}$ and at $20 \pm 2{ }^{\circ} \mathrm{C}$. In between different procedures, they were appropriately stored in zipped plastic bags.

Chemical analyses for water-soluble anions (i.e. acetate, $\left(\mathrm{C}_{2} \mathrm{H}_{3} \mathrm{O}_{2}^{-}\right)$, formate, $\left(\mathrm{HCO}_{2}^{-}\right)$, fluoride, $\left(\mathrm{F}^{-}\right)$, chloride, $\left(\mathrm{Cl}^{-}\right)$, nitrite, $\left(\mathrm{NO}_{2}^{-}\right)$, nitrate, $\left(\mathrm{NO}_{3}^{-}\right)$, phosphate, $\left(\mathrm{PO}_{4}^{3-}\right)$, sulfate, $\left(\mathrm{SO}_{4}^{2-}\right)$, and oxalate, $\left.\left(\mathrm{C}_{2} \mathrm{O}_{4}^{2-}\right)\right)$ and water-soluble cations (i.e. sodium, $\left(\mathrm{Na}^{+}\right)$, potassium, $\left(\mathrm{K}^{+}\right)$, ammonium, $\left(\mathrm{NH}_{4}^{+}\right)$, magnesium, $\left(\mathrm{Mg}^{2+}\right)$, and calcium $\left.\left(\mathrm{Ca}^{2+}\right)\right)$ were performed using ion chromatography (IC) on a ICS-5000 ${ }^{+}$DP Dionex system (Thermo Scientific, USA). Analyses were performed within a week from sampling, in aqueous extracts of the collected samples. For chemical analysis, steps in the analytical procedures were strictly quality controlled to avoid contamination.

After sampling and all other required preparative steps, one half of each collected filter was ultrasonically extracted for $45 \mathrm{~min}$ in $5 \mathrm{~mL}$ deionized water (resistivity of 18.2 M $\Omega . \mathrm{cm}$ ) produced by a Milli-Q Advantage A10 system (Millipore). Filtered extracts $(0.2 \mu \mathrm{m}$ pore size cellulose acetate filters, Advantec) were analysed on an IonPac CS12A $(4 \times 250 \mathrm{~mm})$ analytical column for cations and an IonPac AS22 $(4 \times 250 \mathrm{~mm})$ column for anions, running simultaneously on the IC system. The chromatographic instrumental set-up was completed by CSRS $300 \times 4 \mathrm{~mm}$ and AERS $500 \times 4 \mathrm{~mm}$ electrochemical suppressors and conductivity detectors. Ion analyses were performed under isocratic elution mode, using $\mathrm{CO}_{3}^{2-} / \mathrm{HCO}_{3}^{-}(4.5 / 1.4 \mathrm{mM}$, $1.2 \mathrm{~mL} \mathrm{~min}^{-1}$ ) as the mobile phase for anions and methanesulfonic acid ( $20 \mathrm{mM}, 1.0 \mathrm{~mL} \mathrm{~min}^{-1}$ ) for cations.

Traceable standard solutions (Dionex Seven Anions II and Dionex Six Cations II) were used to generate calibration curves for each species of interest, all with correlation coefficients $R^{2}$ well above 0.995 . The detection limits of the major species (defined as 3 times the standard deviation of blank measurements relative to the method sensitivity) on a $36 \mathrm{~h}$ measurement period were 
$0.0003 \mu \mathrm{g} \mathrm{m}^{-3}$ for $\mathrm{NH}_{4}^{+}(3.2 \mu \mathrm{g} \mathrm{L}-1), 0.001 \mu \mathrm{g} \mathrm{m}^{-3}$ for $\mathrm{Na}^{+}\left(13.4 \mu \mathrm{g} \mathrm{L}^{-1}\right), 0.0015 \mu \mathrm{g} \mathrm{m}^{-3}$ for $\mathrm{K}^{+}\left(19.8 \mu \mathrm{g} \mathrm{L}{ }^{-1}\right)$, $0.0002 \mu \mathrm{g} \mathrm{m}^{-3}$ for $\mathrm{Mg}^{2+}\left(3.2 \mu \mathrm{g} \mathrm{L}^{-1}\right), 0.0016 \mu \mathrm{g} \mathrm{m}^{-3}$ for $\mathrm{Ca}^{2+}\left(20.6 \mu \mathrm{g} \mathrm{L}^{-1}\right), 0.0010 \mu \mathrm{g} \mathrm{m}^{-3}$ for $\mathrm{SO}_{4}^{2-}\left(13.2 \mu \mathrm{g} \mathrm{L}^{-1}\right)$, $0.0012 \mu \mathrm{g} \mathrm{m}{ }^{-3}$ for $\mathrm{NO}_{3}^{-}\left(15.1 \mu \mathrm{g} \mathrm{L}^{-1}\right)$, and $0.0019 \mu \mathrm{g} \mathrm{m}{ }^{-3}$ for $\mathrm{Cl}^{-}\left(24.9 \mu \mathrm{g} \mathrm{L}{ }^{-1}\right)$. Ion concentrations in analysed blank filters (laboratory and field) were subtracted from their corresponding concentrations in the aerosol samples.

The sum of the detected ions, or of the gravimetrically determined mass concentration, over all DLPI stages is hereafter termed " $\mathrm{PM}_{10}$ fraction", while the sum over impactor stages from 1 to 10 is termed " $\mathrm{PM}_{2.5}$ fraction". Modal diameters of the size-segregated aerosol particles or of the analysed ionic components (individual or as a sum) were determined by fitting lognormal distributions.

\subsection{Estimation of the aerosol acidity}

The thermodynamic model proposed by Fountoukis and Nenes (2007), i.e. ISORROPIA-II (http://isorropia.eas. gatech.edu/), was used to get an estimate of the in situ potential acidity of our $\mathrm{PM}_{2.5}$ fractions. The ISORROPIA-II thermodynamic equilibrium model calculates the gas-liquidsolid equilibrium partitioning of $\mathrm{K}^{+}, \mathrm{Ca}^{2+}, \mathrm{Mg}^{2+}, \mathrm{NH}_{4}^{+}$, $\mathrm{Na}^{+}, \mathrm{SO}_{4}^{2-}, \mathrm{NO}_{3}^{-}, \mathrm{Cl}^{-}$, and aerosol water content, and it can predict particle $\mathrm{pH}$. Up to now the model has been used in various field campaigns' data analysis (Nowak et al., 2006; Fountoukis et al., 2009).

To obtain the best predictions of aerosol $\mathrm{pH}$, ISORROPIAII was run in the "forward mode" for the metastable aerosol state, as preliminary runs of the experimental data in the "reverse mode" did not supply suitable information. In the metastable mode the aerosol is assumed to be present only in the aqueous phase, either supersaturated or not (Fountoukis and Nenes, 2007). As model input data we used just aerosolphase ion concentrations measured with IC, along with RH and temperature data from the Hawk GSM-240 weather station. Actually, in the absence of accompanying gas-phase data required to constrain the thermodynamic models, the accuracy of aerosol $\mathrm{pH}$ predictions can be enhanced by using the aerosol concentrations in forward mode calculations (Guo et al., 2015; Hennigan et al., 2015), which seem to be less sensitive to measurement errors than the reverse mode. Where required, $\mathrm{NH}_{3}$ data predicted by ISORROPIA-II were used for the interpretation of the results.

\subsection{Air mass back trajectories and air mass origin}

Air mass back trajectories were calculated using the HYSPLIT 4 model of the NOAA Air Resources Laboratory (Stein et al., 2015; Rolph et al., 2017). Arriving at the investigated site at 18:00 local time (15:00 UTC), $48 \mathrm{~h}$ back trajectories were computed at 500,1000, and $2000 \mathrm{~m}$ altitude above the ground level. Four major sectors of air mass origin were distinguished, and their contributions are shown in Fig. 1. The most and least frequent sectors were the north-eastern (N-E, $36.6 \%$ ) and the south-south-eastern (S-SE, $11.4 \%$ ) ones, respectively. The W-SW sector mainly prevails during winter, while the NE sector is most common during summer. The NW sector had a slightly enhanced frequency in winter and summer that, according to James (2007), could reflect a possible European monsoon circulation. Events from the S-SE sector, prevailing mainly in spring, carried out marine chemical features highly influenced by the Black Sea. Air masses undertaking faster vertical transport most probably due to the locally or continentally driven buoyancy (Holton, 1979; Seinfeld and Pandis, 1998), travelling above large (long-range transport) or short (local) continental areas, were also identified. For instance, in April 2016 five sampled events out of a total of eight were highly influenced by fast vertical air mass transport. In these events, air masses from both 500 and $1000 \mathrm{~m}$ altitude went down to below $500 \mathrm{~m}$ (brushing the ground surface), with a strong impact on the chemical composition of the collected particles (vide infra).

\section{Results and discussion}

\subsection{Variability in $\mathbf{P M}_{10}$ and $\mathbf{P M}_{2.5}$ mass concentrations}

Table 1 shows summary statistics (median, geometric mean, arithmetic mean, standard deviation, minimum, and maximum) for $\mathrm{PM}_{10}$ and $\mathrm{PM}_{2.5}$ mass concentrations at the AMOS site for both working days and weekends. Statistical tests were applied to determine whether there are significant differences among working days and weekends. The Shapiro-Wilk normality test applied to both $\mathrm{PM}_{2.5}$ and $\mathrm{PM}_{10}$ indicated that the entire database was normally distributed (detailed statistics are given in Table S1 in the Supplement). Moreover, the difference in the mean values of the two groups was not high enough to exclude random sampling variability, thereby suggesting that the differences are not statistically significant. Therefore, local anthropogenic activities seem to bring similar contribution to the aerosol burden in the area on both working days and weekends. However, the $\mathrm{PM}_{10}$ annual mean mass concentration $\left(18.95 \mu \mathrm{g} \mathrm{m}^{-3}\right)$ did not exceed the WHO $20 \mu \mathrm{g} \mathrm{m}^{-3}$ air annual mean value, while the $\mathrm{PM}_{2.5}$ annual mean mass concentration $\left(16.92 \mu \mathrm{g} \mathrm{m}^{-3}\right)$ exceeded the $10 \mu \mathrm{g} \mathrm{m}^{-3}$ air annual mean value set by WHO (2006b).

Table 2 presents the annual and/or seasonal arithmetic means of $\mathrm{PM}_{10}$ and $\mathrm{PM}_{2.5}$ mass concentrations in Iasi, compared to other European sites (mean $\pm \mathrm{SD}$ ). The annual averages obtained in the present work show differences in comparison with those reported by Arsene et al. (2011) for the same site. Arsene et al. (2011) have used a SFU system consisting of a $8.0 \mu \mathrm{m}$ pore size, $47 \mathrm{~mm}$ diameter Isopore polycarbonate filter mounted in front of a $0.4 \mu \mathrm{m}$ pore size, $47 \mathrm{~mm}$ diameter Isopore filter. However, the values determined in the present work for the fractions $\mathrm{PM}_{0.027-1.6}$ 

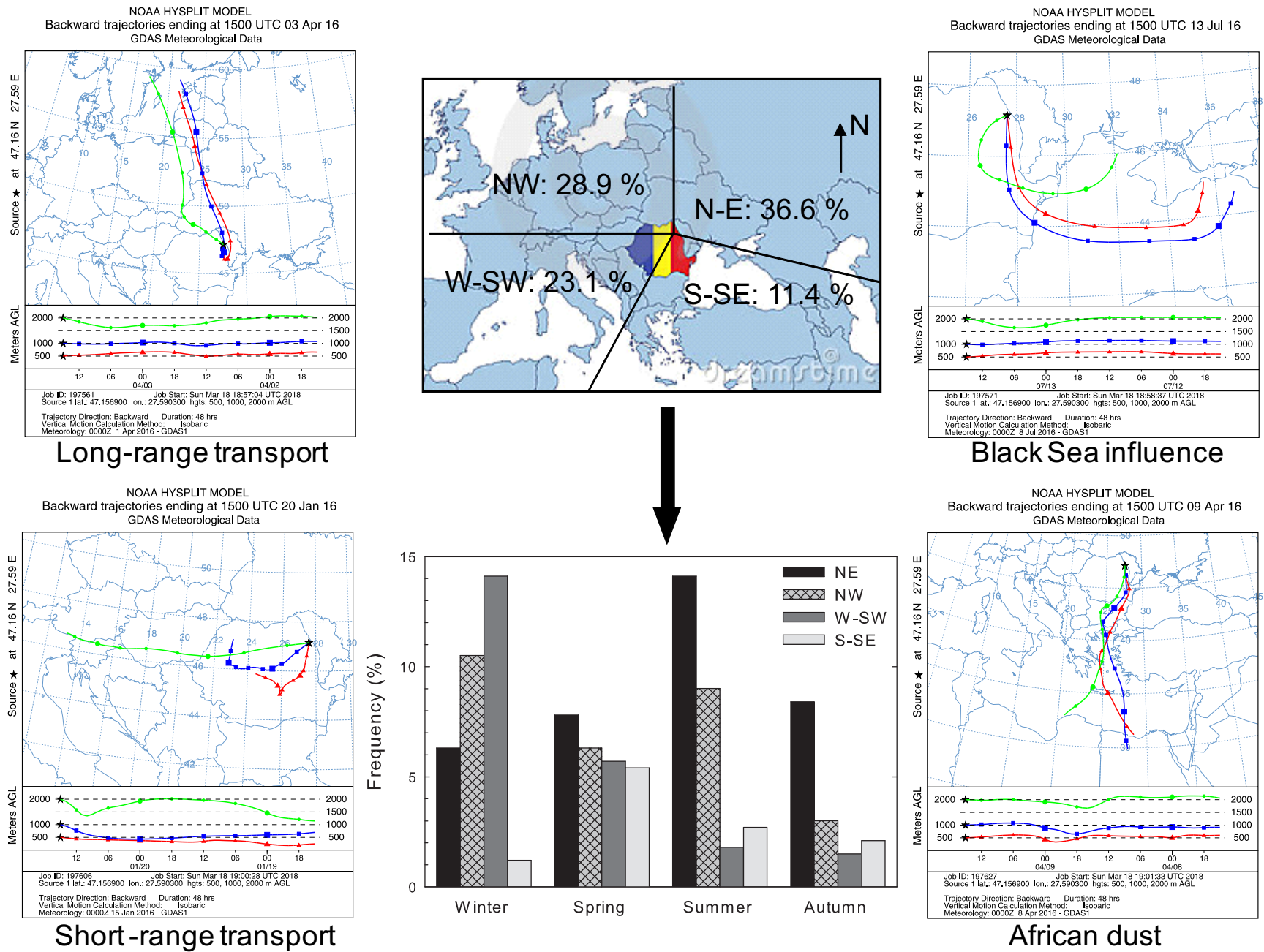

African dust

Figure 1. Sector contributions identified from classification of 2-day back trajectories of air masses ending at Iasi and representative backward trajectories of long- and short-range transport, Black Sea influence, and African dust (shown trajectories correspond to sampling events).

Table 1. Basic statistics for the $\mathrm{PM}_{10}$ and $\mathrm{PM}_{2.5}$ fractions' mass concentrations determined over the investigated period ( $n=84$ sampling events) in Iasi, north-eastern Romania.

\begin{tabular}{lrrr|rrr}
\hline \multirow{2}{*}{ Statistical parameter } & \multicolumn{3}{c|}{$\mathrm{PM}_{10}\left(\mu \mathrm{g} \mathrm{m}^{-3}\right)$} & \multicolumn{3}{c}{$\mathrm{PM}_{2.5}\left(\mu \mathrm{g} \mathrm{m}^{-3}\right)$} \\
\cline { 2 - 7 } & Working day & Weekend & Annual & Working day & Weekend & Annual \\
\hline Mean & 19.25 & 18.60 & 18.95 & 17.31 & 16.47 & 16.92 \\
Median & 16.05 & 17.26 & 16.35 & 14.01 & 15.43 & 14.51 \\
Geomean & 16.90 & 16.91 & 16.90 & 14.86 & 14.83 & 14.84 \\
SD & 10.05 & 8.62 & 9.35 & 9.92 & 8.11 & 9.07 \\
Min & 5.56 & 7.11 & 5.56 & 5.08 & 6.30 & 5.08 \\
Max & 42.65 & 44.84 & 44.84 & 41.57 & 43.91 & 43.91 \\
\hline
\end{tabular}

$\left(15.6 \pm 8.7 \mu \mathrm{g} \mathrm{m}^{-3}\right)$ and $\mathrm{PM}_{0.381-1.6}\left(9.1 \pm 5.6 \mu \mathrm{g} \mathrm{m}^{-3}\right)$ are much closer to those reported by Arsene et al. (2011) for $\mathrm{PM}_{1.5}\left(10.5 \pm 11.2 \mu \mathrm{g} \mathrm{m}^{-3}\right)$. The potential influence on the PM levels of particle size cut-off, differences in sampling site altitude, occurrence of precipitation events, long-range trans- port phenomena, and air mass buoyancy is presented in detail in Sect. S1 in the Supplement.

Figure 2 shows monthly arithmetic mean mass concentrations ( \pm standard deviations) of $\mathrm{PM}_{10}$ and $\mathrm{PM}_{2.5}$ in Iasi. The distribution of the $\mathrm{PM}_{2.5} / \mathrm{PM}_{10}$ ratio is presented in the same figure. The relative contribution of $\mathrm{PM}_{2.5}$ toward $\mathrm{PM}_{10}$ 
Table 2. Annual and/or seasonal arithmetic means of the $\mathrm{PM}_{10}$ and $\mathrm{PM}_{2.5}$ fraction mass concentrations in Iasi, north-eastern Romania, and other various European sites (mean $\pm \mathrm{SD})$.

\begin{tabular}{|c|c|c|c|c|c|c|}
\hline \multirow[t]{2}{*}{ Site } & \multirow[t]{2}{*}{ Category } & \multirow{2}{*}{$\begin{array}{l}\text { Sampling } \\
\text { aa.g.1. }{ }^{1}(\mathrm{~m})\end{array}$} & \multirow[t]{2}{*}{ Sampling period } & \multirow{2}{*}{$\frac{\mathrm{PM}_{2.5}}{\left(\mu \mathrm{g} \mathrm{m}^{-3}\right)}$} & \multirow{2}{*}{$\frac{\mathrm{PM}_{10}}{\left(\mu \mathrm{g} \mathrm{m}^{-3}\right)}$} & \multirow[t]{2}{*}{ Reference } \\
\hline & & & & & & \\
\hline Iasi (Romania) & Urban & 35 & 2016 & $16.9 \pm 9.1$ & $18.9 \pm 9.3$ & This work \\
\hline & & & & $14.0 \pm 7.1($ warm $)$ & $16.8 \pm 8.3($ warm $)$ & \\
\hline & & & & $21.3 \pm 13.0($ cold $)$ & $22.6 \pm 13.1($ cold $)$ & \\
\hline & & & & $15.6 \pm 8.7^{2}$ & - & \\
\hline & & & & $9.1 \pm 5.5^{3}$ & - & \\
\hline Iasi (Romania) & Urban & 25 & 2007-2008 & $10.5 \pm 11.2$ & $38.3 \pm 25.4$ & Arsene et al. $(2011)^{4}$ \\
\hline Paris (France) & Urban background & 20 & 2009-2010 & $14.8 \pm 9.6$ & - & Bressi et al. (2013) \\
\hline Northern Europe (SE12) & $\begin{array}{l}\text { EMEP and four regional } \\
\text { background sites }\end{array}$ & - & 2012-2013 & - & $3-8$ & Alastuey et al. $(2016)^{5}$ \\
\hline North-western Europe (IE321) & & & & & $10-15(\mathrm{~S}) ; \sim 35(\mathrm{~W})$ & \\
\hline Central western Europe (FR09) & & & & & $10-15(\mathrm{~S}) ; \sim 25(\mathrm{~W})$ & \\
\hline Central Europe (DE44) & & & & & $20-25(\mathrm{~S}) ; 25-30(\mathrm{~W})$ & \\
\hline Eastern Europe (SK06, HU02) & & & & & $10-15(\mathrm{~S}) ; 15-25(\mathrm{~W})$ & \\
\hline Eastern Europe (MD13) & & & & & $\sim 25(\mathrm{~S}) ; 25-30(\mathrm{~W})$ & \\
\hline South-western Europe (ES22) & & & & & $20-25(\mathrm{~S}) ; 5-10(\mathrm{~W})$ & \\
\hline Central southern Europe (IT01) & & & & & $25-35(\mathrm{~S}) ; 20-25(\mathrm{~W})$ & \\
\hline South-eastern Europe (GR02) & & & & & $\sim 25(\mathrm{~S}) ; 35-40(\mathrm{~W})$ & \\
\hline Thessaloniki (Greece) & Urban & 7 & 2011-2012 & $37.7 \pm 15.7$ & - & Tolis et al. (2015) \\
\hline Thessaloniki (Greece) & Urban & 3 & 2011-2012 & $\begin{array}{l}21.5 \pm 8.3(\text { warm }) \\
33.9 \pm 19.3(\text { cold })\end{array}$ & - & Voutsa et al. $(2014)^{6}$ \\
\hline Finokalia (Greece) & Remote coastal & $\sim 5$ & 2004-2006 & 18.2 & 30.8 & Gerasopoulos et al. (2007) \\
\hline Bologna (Italy) & Urban background & Courtyard & 2005-2006 & $31.6 \pm 21.0$ & $44.5 \pm 24.2$ & Tositti et al. (2014) \\
\hline Venice (Italy) & Semi-rural coastal & - & $2007-2008$ & - & $22.5 \pm 12.9$ & Masiol et al. (2012) \\
\hline Prague (Czech) & Urban & $12-25$ & 2004-2005 & - & $33 \pm 13$ & Schwarz et al. (2008) \\
\hline
\end{tabular}

showed low variability amongst the months of the year, with ratios ranging from $\sim 0.75$ to $\sim 1.0$. For urban background and/or traffic sites, WHO (2006a) suggests $\mathrm{PM}_{2.5} / \mathrm{PM}_{10}$ ratios in the $0.42-0.82$ range. Seasonal patterns, with maxima during the cold season and minima during the warm season, are observed for all of the $\mathrm{PM}_{2.5}, \mathrm{PM}_{10}$, and $\mathrm{PM}_{2.5} / \mathrm{PM}_{10}$ profiles and might be the combined result of seasonal emissions variations, local- and long-range air transport and dispersion, chemical processes, and deposition (Wang et al., 2016). The maxima of $\mathrm{PM}_{2.5} / \mathrm{PM}_{10}$ during the cold season are most probably caused by combustion processes as the burning of coal or petroleum for heating purposes enhances secondary aerosol generation ( $\mathrm{Li}$ et al., 2012). The lower $\mathrm{PM}_{2.5} / \mathrm{PM}_{10}$ values during the warm season might be due to dust events and to more intense anthropogenic activities near the sampling site (e.g. excavation, construction, and building renewal) that would cause higher loading of coarse particles in the atmosphere. As suggested by Zhang et al. (2001), various land use categories (e.g. grass, crops, mixed farming, shrubs) corroborated with other particle-related characteristics (i.e. particle density, relevant meteorological variables) may enhance the dry deposition of sub-micron particles during the warm season and hence their fine / coarse ratio.

Another clear seasonal pattern was observed for the mass concentration size distribution (Fig. 3). Over the cold season, it had a clear monomodal feature with a maximum at $381 \mathrm{~nm}$. In contrast, the warm season was characterized by the same

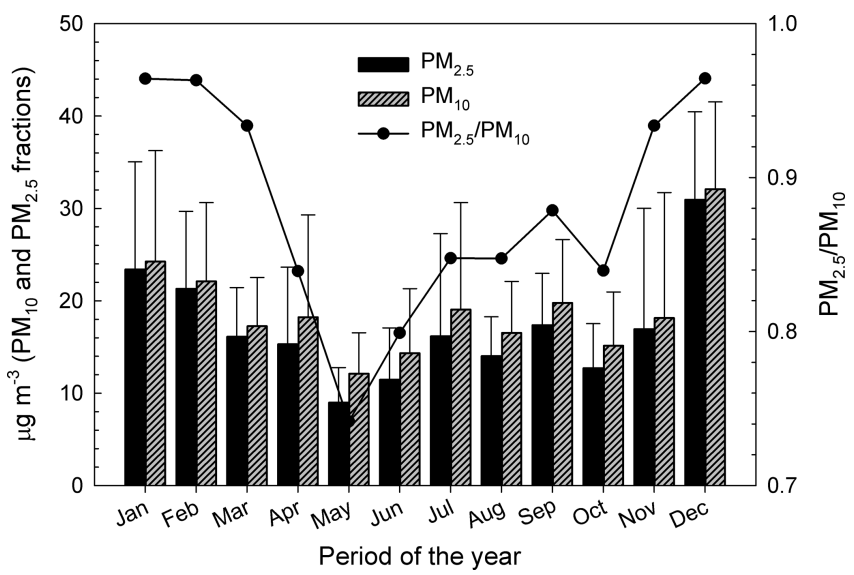

Figure 2. Patterns of the monthly arithmetic mean concentrations and standard deviations in the $\mathrm{PM}_{10}, \mathrm{PM}_{2.5}$, and $\mathrm{PM}_{2.5} / \mathrm{PM}_{10}$ variables at Iasi, north-eastern Romania.

dominant fine mode, but also by the occurrence of a supermicron mode between 1.60 and $2.39 \mu \mathrm{m}$. Again, changes in source contributions and meteorological conditions could account for the observed differences (details in Sect. S2). 


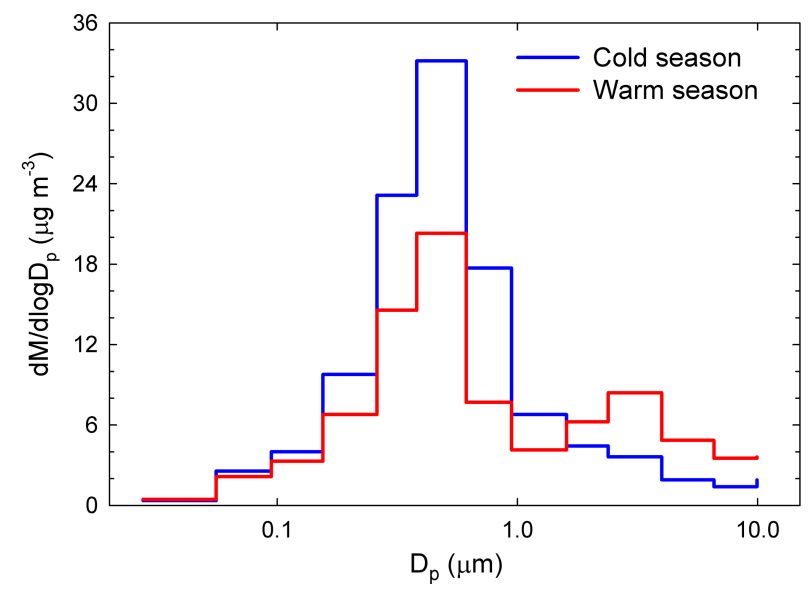

Figure 3. Size distribution histograms of aerosol particle mass concentration gravimetrically determined over both the cold and warm seasons.

\subsection{Ionic balance, seasonality of water-soluble ions, and stoichiometry of $\left(\mathrm{NH}_{4}\right)_{2} \mathrm{SO}_{4}$ and $\mathrm{NH}_{4} \mathrm{NO}_{3}$}

\subsubsection{Ionic balance and potential aerosol acidity}

The completeness of the ionic balance was checked for the identified and quantified species $\left(\mathrm{F}^{-}, \mathrm{Cl}^{-}, \mathrm{NO}_{2}^{-}, \mathrm{NO}_{3}^{-}\right.$, $\mathrm{PO}_{4}^{3-}, \mathrm{SO}_{4}^{2-}, \mathrm{HCO}_{2}^{-}, \mathrm{C}_{2} \mathrm{H}_{3} \mathrm{O}_{2}^{-}, \mathrm{C}_{2} \mathrm{O}_{4}^{2-}, \mathrm{Na}^{+}, \mathrm{K}^{+}, \mathrm{NH}_{4}^{+}$, $\mathrm{Mg}^{2+}$, and $\mathrm{Ca}^{2+}$ ) in both $\mathrm{PM}_{10}$ and $\mathrm{PM}_{2.5}$. The slopes in the raw IC data related to $\sum_{\text {cations }}$ vs. $\sum_{\text {anions }}$ were $<1$ in both $\mathrm{PM}_{2.5}$ and $\mathrm{PM}_{10}$ (detailed statistics in Table S2), pointing to an important cation deficit that was higher in the cold compared to the warm season. However, for each sampling event, either cation or anion deficit was observed in various impactor stages. It should also be noted that, at the investigated site, a RH of $\sim 82 \%$ was even observed during the cold season.

Predicting $\mathrm{pH}$ is suggested as the best method to analyse particle acidity (Guo et al., 2015). The ion balance method is usually based upon the principle of electroneutrality, and any deficit in measured cationic compared to anionic charge is assigned to the presence of unmeasured protons $\left(\mathrm{H}^{+}\right)$. The reverse occurs for unmeasured hydroxyl $\left(\mathrm{OH}^{-}\right)($Hennigan et al., 2015) or bicarbonate / carbonate $\left(\mathrm{HCO}_{3}^{-} / \mathrm{CO}_{3}^{2-}\right)$ (Fountoukis and Nenes, 2007). In the present work, $\mathrm{HCO}_{3}^{-} / \mathrm{CO}_{3}^{2-}$ was assigned as the missing anion (details in Sect. S3 for $\mathrm{HCO}_{3}^{-} / \mathrm{CO}_{3}^{2-}$ estimation) while $\mathrm{NH}_{4}^{+}$was assigned as the main missing cation (details in Sect. S4 for the missing $\mathrm{NH}_{4}^{+}$assumptions). Detailed statistics of the $\sum_{\text {cations }}$ vs. $\sum_{\text {anions }}$ dependences, with $\mathrm{HCO}_{3}^{-} / \mathrm{CO}_{3}^{2-}$ and missing $\mathrm{NH}_{4}^{+}$ included in the ionic balance, are presented in Table S3.

In an attempt to investigate whether or not the $\mathrm{H}^{+}$species would bring an important contribution within the ionic balance, the ISORROPIA-II thermodynamic equilibrium model proposed by Fountoukis and Nenes (2007) has been used in the present work (more details about ISORROPIA-II can be found in Sect. S5). We investigated the relationship between ISORROPIA-II-predicted aerosol $\mathrm{pH}$ and the ionic balance for the present database, and the results are presented in Fig. 4a. The data remarkably follow a traditional titration curve, and they also clearly show that many of the analysed particles were approximately neutral (dashed lines at 0 ). A very important fraction of the investigated samples were in the acidic range $(\mathrm{pH}<3$ if samples were in cation deficit mode), while the remaining fraction were alkaline ( $\mathrm{pH}$ slightly above 7 with anion deficit mode). However, as suggested by Hennigan et al. (2015), small uncertainties in the ionic balance (mainly due to measurement uncertainties and more likely in approximately neutral conditions) may lead to shifts that span over about $10 \mathrm{pH}$ units. Moreover, the sensitivity to changes in the aerosol $\mathrm{NH}_{4}^{+}$concentration has been checked in predicted aerosol $\mathrm{pH}$ under forward-mode calculation. As shown in Fig. $4 \mathrm{~b}$, it seems that the predicted $\mathrm{pH}$ might decrease by $2 \%$ when the ionic balance takes into account $\mathrm{NH}_{4}^{+}$(total) concentration (defined as the sum between that derived from raw IC data and the part estimated by using the rationale of Arsene et al., 2011). Details on the $\mathrm{pH}$ sensitivity tests for $\mathrm{NH}_{4}^{+}$concentrations are given in Sect. S6.

In Iasi, north-eastern Romania, an important fraction of the total analysed samples were alkaline while the remaining samples were acidic. A more detailed view of the samples' $\mathrm{pH}$ distribution can be obtained from the data presented in Fig. 4c, d. It seems that over the warm season about 55-56\% of the analysed samples were alkaline $(\mathrm{pH}>7)$ and about $44-45 \%$ were acidic $(\mathrm{pH}<7)$, with the last fraction mainly distributed in the very strong acidity fraction $(\sim 35 \%$ of the samples with $\mathrm{pH}$ in the $0-3$ range, and about $2 \%$ with an aerosol $\mathrm{pH}$ less than 0 ). Over the cold season only $47 \%$ of the total analysed samples were alkaline $(\mathrm{pH}>7)$ and $53 \%$ were acidic $(\mathrm{pH}<7)$. The acidity was also mainly distributed in the very strong acidity fraction $(\sim 43 \%$ of the acidic samples with $\mathrm{pH}$ in the $0-3$ range). Sulfuric, nitric, hydrochloric, and formic acids are the most likely contributors to aerosol $\mathrm{pH}$ in the $0-3$ range. Note that strongly acidic aerosols af fect air quality, health of aquatic and terrestrial ecosystems (especially through acid deposition), and atmospheric visibility and climate (Dockery et al., 1996; Gwynn et al., 2000; Hennigan et al., 2015). Possible impacts of strongly acidic aerosols are presented in more detail in Sect. S7. Moreover, aerosol acidity can impact the gas-particle partitioning of semi-volatile organic acids. While under strongly acidic conditions ( $\mathrm{pH} 1-3)$ the $\mathrm{pH}$ contribution of organic acids is expected to be negligible as these conditions prevent their dissociation, the scenario may change completely at $\mathrm{pH}$ values of 3-7 (vide infra). Under these circumstances, formic acid with $\mathrm{pK}_{\mathrm{a}}=3.75$ (Bacarella et al., 1955) might give a significant $\mathrm{pH}$ contribution to $\sim 7 \%$ of the warm season samples and $\sim 10 \%$ of the cold season ones.

Figure $5 \mathrm{a}, \mathrm{b}$ present the size distribution of averaged aerosol mass and $\mathrm{NO}_{3}^{-}, \mathrm{SO}_{4}^{2-}$, and $\mathrm{NH}_{4}^{+}$concentrations 

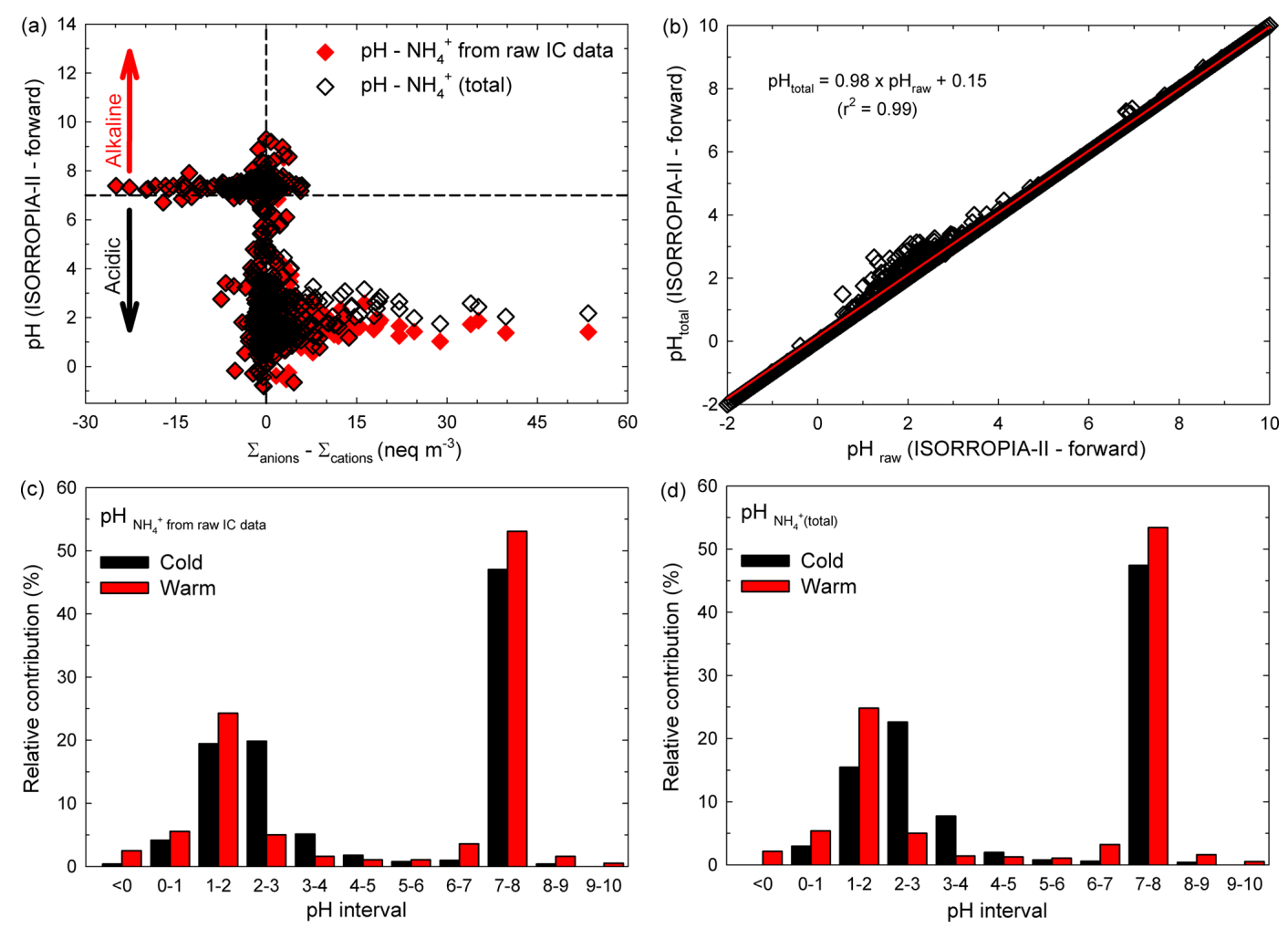

Figure 4. Distribution of the aerosol $\mathrm{pH}$ predicted by ISORROPIA-II (forward mode) vs. the ion balance (a), sensitivity of aerosol pH predicted with the model to small changes in the input aerosol $\mathrm{NH}_{4}^{+}$concentration $(\mathbf{b})$, and bar chart distribution in aerosol $\mathrm{pH}$ over the warm and cold seasons for both $\mathrm{NH}_{4}^{+}$derived from raw $\mathrm{IC}$ data (c) and $\mathrm{NH}_{4}^{+}$(total) (d).

while Fig. 5c, d present ISORROPIA-II estimates for $\mathrm{pH}$ and $\mathrm{H}^{+}$mass concentration distributions, for both the cold (Fig. 5a, c) and the warm (Fig. 5b, d) seasons. Clear monomodal distribution seems to be specific for the cold season, while for the warm season the second mode (1.60$2.39 \mu \mathrm{m})$ mass concentration distribution seems to be predominated by $\mathrm{NO}_{3}^{-}$. For the $155-612 \mathrm{~nm}$ size range, from details presented in Fig. $5 \mathrm{c}, \mathrm{d}$, it is quite clear that $\mathrm{pH} \leq 2$. In the present work, the aerosol $\mathrm{H}^{+}$levels inferred indirectly from the ion balance as proposed by Hennigan et al. (2015) showed statistically significant correlation with the $\mathrm{H}^{+}$loadings predicted by ISORROPIA-II in the forward mode (Pearson coefficient of $0.72, p<0.001$ ). However, despite the good correlation, there were important discrepancies between the two estimated $\mathrm{H}^{+}$levels (intended as absolute values), with those from ISORROPIA-II being considerably lower than those from the ionic balance. The main issue with the model is that it may account only for partial dissociation, while the ionic balance may be affected by the uncertainty due to the propagation of measurement error. The latter may be particularly important in the presence of a slight anion deficit balance, which is interpreted as an $\mathrm{H}^{+}$-loaded system. Despite the uncertainties in the actual $\mathrm{pH}$ values, it is very likely that the $155-612 \mathrm{~nm}$ aerosol particles are strongly acidic and that $\mathrm{H}^{+}$is mainly contributed by completely dissociated strong acids such as $\mathrm{H}_{2} \mathrm{SO}_{4}$ and $\mathrm{HNO}_{3}$. Contributions from free acidity (dissociated $\mathrm{H}^{+}$) or total acidity (free $\mathrm{H}^{+}$and undissociated $\mathrm{H}^{+}$bound to weak acids) are expected to be more important in all other remaining fractions, and especially in the 27.6-94.5 $\mathrm{nm}$ particle size range (vide infra). Of course, a higher confidence in the estimate of particle $\mathrm{pH}$ would allow better prediction of the chemical behaviour of organics that, if dissociated at relatively low acidities, would significantly contribute to the ion balance.

In the literature it is suggested that the molar ratio approach may be a proxy for aerosol $\mathrm{pH}$ estimation (Hennigan et al., 2015). However, such a procedure is highly susceptible to bias in the results, either due to exclusion of minor ionic species or because it does not consider the effects of aerosol water or species activities on particle acidity. In this work, even when the aerosol was inferred to be highly acidic (samples with a molar ratio of $\mathrm{NH}_{4}^{+} /\left(\mathrm{Cl}^{-}+\mathrm{NO}_{3}^{-}+2 \times \mathrm{SO}_{4}^{2-}\right)$ $<0.75$ ), there was no statistically significant correlation between the cation / anion molar ratio and $\left[\mathrm{H}^{+}\right]$from either ion balance or model predictions. Therefore, the molar ratio does not appear to be a suitable tool to infer the acidity of atmospheric particles at the study site, but it could be a good parameter to distinguish between alkaline and acidic particles.

Data on gaseous $\mathrm{NH}_{3}$ were not available, but the potential relationship was also investigated between $\mathrm{NH}_{3} / \mathrm{NH}_{4}^{+}$phase 

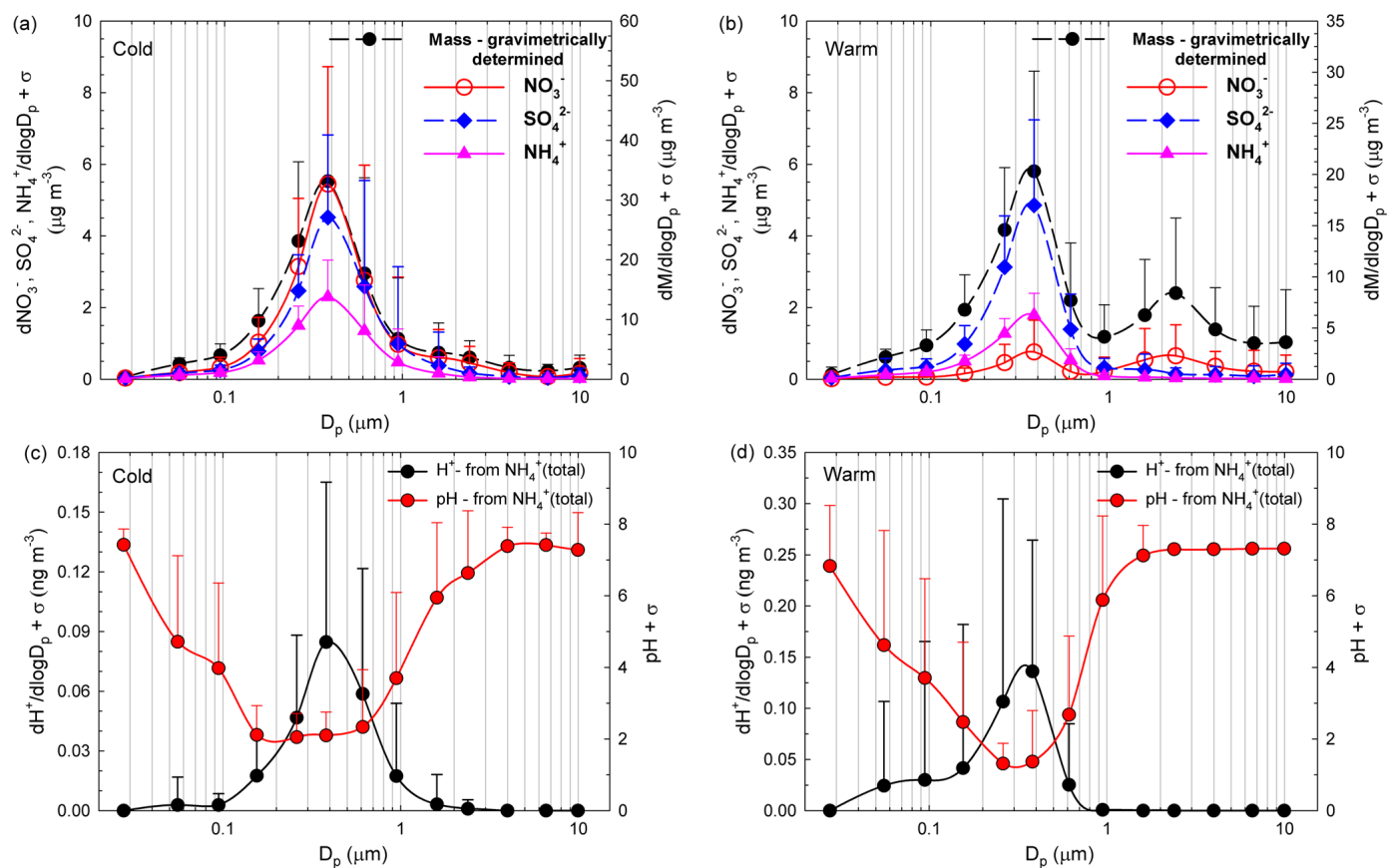

Figure 5. Size distribution of averaged aerosol mass and $\mathrm{NO}_{3}^{-} \mathrm{SO}_{4}^{2-}$, and $\mathrm{NH}_{4}^{+}$concentrations over the cold (a) and warm (b) seasons accompanied by the size distribution of ISORROPIA-II-estimated $\mathrm{pH}$ and $\mathrm{H}^{+}$mass concentration over both the cold (c) and the warm (d) seasons.

partitioning (with $\mathrm{NH}_{3}$ values predicted by ISORROPIA-II) and particle $\mathrm{pH}$. The hypothesis of phase partitioning equilibrium is justified by the fact that the sampling time interval $(36 \mathrm{~h})$ was much longer than the equilibration time for submicron particles (seconds to minutes; Meng et al., 1995). As previously mentioned, in the present work the number of samples with a $\mathrm{pH}<0$ was significantly lower compared to those with a $\mathrm{pH}>0$. Moreover, ISORROPIA-II predicted that in the $94.5-612 \mathrm{~nm}$ size range there would be a significant $\mathrm{NH}_{3}$ fraction in the gas phase.

The detailed $\mathrm{NH}_{3} / \mathrm{NH}_{4}^{+}$partitioning as a function of $\mathrm{RH}$ is presented below, and considerations on the potential effects on the partitioning brought about by changes in the $\mathrm{SO}_{4}^{2-}$ and $\mathrm{NO}_{3}^{-}$concentrations, and by temperature affecting both $\mathrm{SO}_{4}^{2-}$ and $\mathrm{NO}_{3}^{-}$production, is given in Sect. $\mathrm{S} 8$. The potential role played by temperature on $\mathrm{NH}_{3} / \mathrm{NH}_{4}^{+}$ partition seems to be minimal, but one should also consider that highly acidic aerosols will affect a variety of processes and definitely the partitioning of $\mathrm{HNO}_{3}$ to the gas phase, producing low nitrate aerosol levels. ISORROPIAII runs predicted gas-phase $\mathrm{NH}_{3}$ concentrations in Iasi as high as $0.52 \pm 0.28(0.46)($ mean $\pm \mathrm{SD}$ (median) $) \mu \mathrm{g} \mathrm{m}{ }^{-3}$ at $\mathrm{RH}<40 \%, 0.61 \pm 0.26(0.49) \mu \mathrm{g} \mathrm{m}^{-3}$ at $\mathrm{RH}=40-60 \%$, and $0.96 \pm 0.54(0.92) \mu \mathrm{g} \mathrm{m}^{-3}$ at $\mathrm{RH}>60 \%$. These warm season values are smaller than those reported in a modelling study by Backes et al. (2016), who predicted $\mathrm{NH}_{3}$ abundances as high as 1.6 to $2.4 \mu \mathrm{g} \mathrm{m}^{-3}$ (data extracted from $\mathrm{NH}_{3}$ concentration for the reference case, i.e. Fig. 3 in
Backes et al., 2016, for north-eastern Romania). In contrast, the $0.96 \pm 0.54(0.92) \mu \mathrm{g} \mathrm{m}^{-3}$ value at $\mathrm{RH}>60 \%$, which would be mainly found during the cold season, seems to be in reasonable agreement with the $\leq 0.8 \mu \mathrm{g} \mathrm{m}^{-3}$ value modelled by Backes et al. (2016) over winter. Moreover, from ISORROPIA-II runs performed at $\mathrm{RH}<40 \%$, it was estimated that $(77.6 \pm 28.4) \%$ or $(79.3 \pm 26.2) \%($ mean $\pm S D)$ of the $\mathrm{NH}_{3}$ predicted by ISORROPIA-II could be present in the gaseous phase (with reference to both $\mathrm{NH}_{4}^{+}$derived from raw IC data and to the $\mathrm{NH}_{4}^{+}$(total) fraction). Similar but slightly decreasing values were predicted for gas-phase $\mathrm{NH}_{3}$ as RH increased, namely $(76.5 \pm 30.9) \%$ or $(78.6 \pm 28.2) \%$ (raw IC and $\mathrm{NH}_{4}^{+}$(total), respectively) at $\mathrm{RH}=40-60 \%$ and $(68.3 \pm 36.7) \%$ or $(74.5 \pm 29.7) \%$ at $\mathrm{RH}>60 \%$.

In other studies, thermodynamic equilibrium calculations predicted that all of the $\mathrm{NH}_{3}$ was mainly susceptible to partitioning to the particle phase at the equilibrium, and also that $>44$ or $51 \%$ of the investigated samples presented an aerosol $\mathrm{pH}<0$ (Hennigan et al., 2015). However, it seems that at the investigated Romanian site the atmosphere could be rich enough in $\mathrm{NH}_{3}$ so as to allow its occurrence in the gas phase while also promoting particle-phase partitioning. The seasonal trends in the $\mathrm{NH}_{3}$ concentrations derived from ISORROPIA runs for Iasi are reported in Fig. S1 (Sect. S9). The same section reports considerations on possible interrelated emission factors governing the distribution in the $\mathrm{NH}_{3}$ concentration levels in Iasi. 
The ISORROPIA-II data referring to the $155-612 \mathrm{~nm}$ size range (regardless of $\mathrm{RH}$ ) suggested that the aerosol ammonium fraction $\left(\mathrm{NH}_{4}^{+} /\left(\mathrm{NH}_{3}+\mathrm{NH}_{4}^{+}\right)\right)$was over 0.20 irrespective of the calculation procedure (raw IC or $\mathrm{NH}_{4}^{+}$(total)). Clear $\left(\mathrm{NH}_{4}^{+} /\left(\mathrm{NH}_{3}+\mathrm{NH}_{4}^{+}\right)\right)$maxima were observed at $381 \mathrm{~nm}$ (raw IC data: 0.71 at $\mathrm{RH}<40 \%, 0.63$ at $\mathrm{RH}=40$ $60 \%$, and 0.76 at $\mathrm{RH}>60 \% ; \mathrm{NH}_{4}^{+}$(total), defined as the sum between that derived from raw IC data and the part estimated by using the rationale of Arsene et al. (2011): 0.66 at $\mathrm{RH}<40 \%, 0.56$ at $\mathrm{RH}=40-60 \%, 0.65$ at $\mathrm{RH}>60 \%$ ). As seen in Fig. 5c, d, the aerosol pH is very low in the 155$612 \mathrm{~nm}$ size range, while it often approaches 8 in the 27.694.5 and $612-9940 \mathrm{~nm}$ size ranges. Although not presented, in the $155-612 \mathrm{~nm}$ size range the aerosol ammonium fraction $\left(\mathrm{NH}_{4}^{+} /\left(\mathrm{NH}_{3}+\mathrm{NH}_{4}^{+}\right)\right)$approaches 1 , while in other two size ranges it is very low or close to 0 , thereby suggesting the occurrence of gaseous $\mathrm{NH}_{3}$.

\subsubsection{Seasonality of the major water-soluble ions}

Table 3 shows monthly statistics for meteorological variables and mass concentrations of $\mathrm{PM}_{10}, \mathrm{PM}_{2.5}$, and major water-soluble ions in $\mathrm{PM}_{2.5}$. Compared to the $\mathrm{PM}_{2.5}$ fraction, in the $\mathrm{PM}_{10}$ fraction we observed increases in the mass concentrations of the following ions (notation for the $\%$ increase: $\min -\max \left(\right.$ mean)): $13-80 \%(35 \%)$ for $\mathrm{Cl}^{-} ; 1-$ $107 \%(32 \%)$ for $\mathrm{NO}_{3}^{-} ; 1-170 \%(17 \%)$ for $\mathrm{SO}_{4}^{2-} ; 38-185 \%$ (63\%) for $\mathrm{HCO}_{3}^{-} ; 14-171 \%$ (41\%) for acetate; $4-136 \%$ (22\%) for formate; $0-294 \%$ (27\%) for oxalate; $16-48 \%$ (32\%) for $\mathrm{Na}^{+} ; 6-58 \%(20 \%)$ for $\mathrm{K}^{+} ; 1-105 \%(12 \%)$ for $\mathrm{NH}_{4}^{+}$(total); $28-83 \%$ (46\%) for $\mathrm{Mg}^{2+}$, and 33-123\% (61\%) for $\mathrm{Ca}^{2+}$. However, the $\mathrm{PM}_{10}$ and $\mathrm{PM}_{2.5}$ mass concentration fractions show statistically significant correlation with a ratio of 1.1 (Pearson coefficient of $0.99, p<0.001$ ). Higher mass concentrations of specific water-soluble ions $\left(\mathrm{Cl}^{-}, \mathrm{NO}_{3}^{-}, \mathrm{K}^{+}, \mathrm{NH}_{4}^{+}\right.$, and, to some extent, $\left.\mathrm{SO}_{4}^{2-}\right)$ were observed during the cold compared to the warm season, probably because of the combination of increased strength of pollution sources and meteorological effects (inducing lower mixing heights or even temperature inversion), or due to different chemical or photochemical processing. Although lowering mixing heights over the cold season might increase pollutant concentration in the atmosphere, for some species additional phenomena should be taken into account in order to explain their distribution. For particulate $\mathrm{SO}_{4}^{2-}$, high concentrations can be observed during winter and autumn but also in summer, and in the latter case they can be due to higher temperature and solar radiation that enhance photochemical reactions and the atmospheric oxidation potential because of the elevated occurrence of oxidant species such as ozone, hydroxyl, and nitrate radicals. These conditions favour the oxidation of $\mathrm{SO}_{2}$ to particulate $\mathrm{SO}_{4}^{2-}$. Also particulate $\mathrm{C}_{2} \mathrm{O}_{4}^{2-}$ was maximum in summer, possibly due to enhanced photochemical processing. Moreover, the maxima observed for $\mathrm{SO}_{4}^{2-}$ during the cold season might be due to the intensifica- tion of coal burning for heating purposes. Higher abundances of particulate $\mathrm{NO}_{3}^{-}, \mathrm{SO}_{4}^{2-}, \mathrm{NH}_{4}^{+}$, and $\mathrm{K}^{+}$in winter compared to summer are reported for other European (Schwarz et al., 2012; Voutsa et al., 2014) and non-European sites as well (Sharma et al., 2007). Sharma et al. (2007) also suggest a potential role of $\mathrm{CaCO}_{3}$ in controlling particulate $\mathrm{NO}_{3}^{-}$abundance in Kanpur, India.

Seasonal variations for selected water-soluble ionic components in $\mathrm{PM}_{2.5}$ are shown in Fig. $6 \mathrm{a}-\mathrm{h}$, while Fig. 6i shows the variation in the mixing layer depth at the investigated site. Fine-particulate $\mathrm{Cl}^{-}, \mathrm{NO}_{3}^{-}, \mathrm{K}^{+}, \mathrm{NH}_{4}^{+}$(total), and to some extent even $\mathrm{SO}_{4}^{2-}$ seem to exhibit distinct seasonal variations with maxima during the cold season and minima over the warm season, which might be related to changes in the mixing layer depth. The summer minima observed for both $\mathrm{NO}_{3}^{-}$ and $\mathrm{NH}_{4}^{+}$are not surprising because $\mathrm{NH}_{4} \mathrm{NO}_{3}$ is volatile and tends to dissociate to gas-phase $\mathrm{NH}_{3}$ and $\mathrm{HNO}_{3}$ at high temperatures. Coarse particulate $\mathrm{C}_{2} \mathrm{O}_{4}^{2-}, \mathrm{Ca}^{2+}$, and $\mathrm{Na}^{+}$did not show much variation with respect to seasons. However, $\mathrm{SO}_{4}^{2-}$ and $\mathrm{C}_{2} \mathrm{O}_{4}^{2-}$ showed similar patterns (implying most probably common sources), and the $\mathrm{Ca}^{2+}$ trend suggests prevalent contribution from soil dust. Higher ion concentrations in winter than in summer are reported by Sharma et al. (2007) for Kanpur (India), while Ianniello et al. (2011) report opposite trends for Beijing (China).

Particulate $\mathrm{Cl}^{-}$mass concentrations show a clear seasonal pattern, with higher values during the cold season than during the warm season (Fig. 6a). The chloride mass concentration in both $\mathrm{PM}_{2.5}$ and $\mathrm{PM}_{10}$ had a statistically significant correlation with $\mathrm{RH}$, temperature (only for $\mathrm{PM}_{10}$ fraction), particle loading, and mixing layer depth (detailed statistics in Table S4). The chloride maxima during the cold season might be the result of increased coal burning for heating purposes or of the use of $\mathrm{NaCl}$ in winter on icy and snowy roads. These observations are in agreement with other studies at eastern European sites (Arsene et al., 2011; Alastuey et al., 2016). However, the $\mathrm{Cl}^{-}$mass concentration follows a pattern similar to that of $\mathrm{K}^{+}$(tracer of biomass burning), thereby suggesting that over the cold season wood burning might become an important heating source (Christian et al., 2010; Akagi et al., 2011).

Nitrate also shows cold season maxima and warm season minima (see Table 3 and Fig. 6b). The inset distribution presented within $\mathrm{NO}_{3}^{-}$seasonal variation (Fig. 6b) suggests that, in summer, the coarse PM fraction can bring significant contributions to the aerosol atmospheric burden of nitrate. In our work, fine-particulate $\mathrm{NO}_{3}^{-}$mass concentrations varied from 0.31 to $3.62 \mu \mathrm{g} \mathrm{m}^{-3}$ (Table 3) and these data are in very good agreement with those predicted for $\mathrm{Eu}-$ rope in a modelling study performed by Backes et al. (2016). The data obtained in the present work over the cold season $\left(3.62 \pm 1.10 \mu \mathrm{g} \mathrm{m}^{-3}\right.$ in January, February, and December as the coldest months of the year, and $2.65 \pm 0.38 \mu \mathrm{g} \mathrm{m}^{-3}$ over January, February, March, October, November, and Decem- 


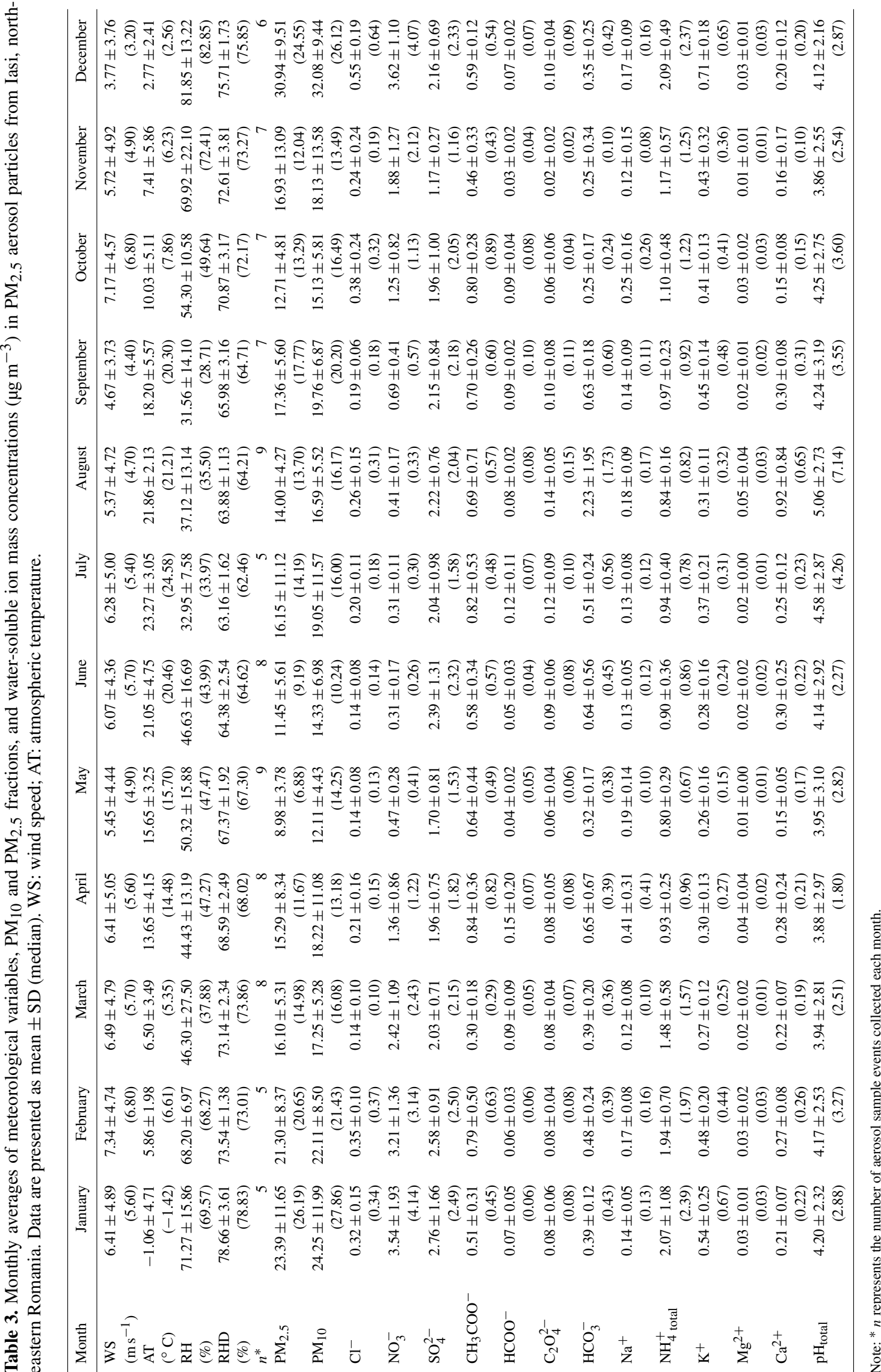



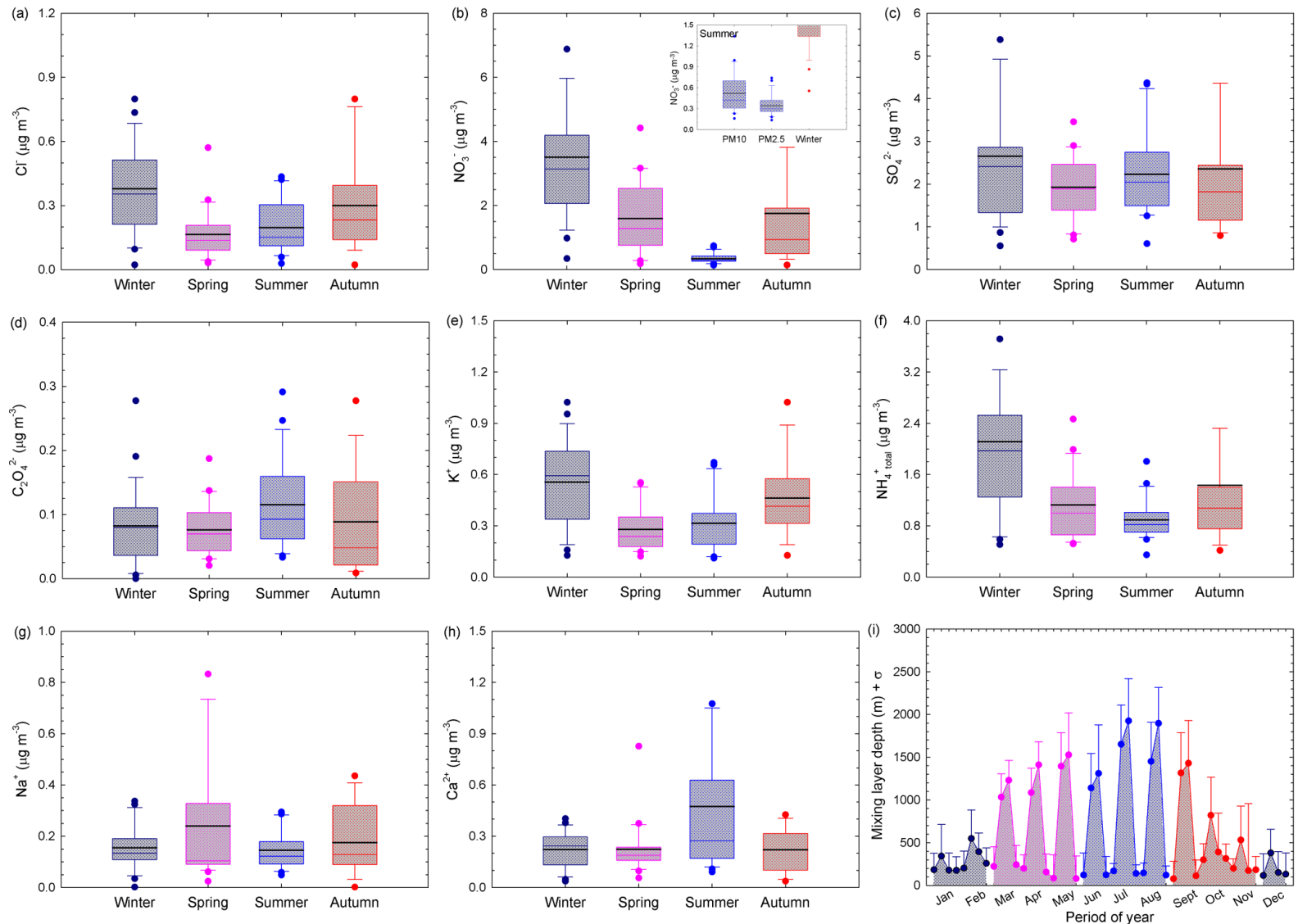

Figure 6. Seasonal variations for selected water-soluble ionic components in the $\mathrm{PM}_{2.5}$ fraction (a-h) and variation in the mixing layer depth at the investigated site (i). The inset distribution presented within $\mathrm{NO}_{3}^{-}$seasonal variation reflects the contribution of the coarse fraction over the warm season. The horizontal black line represents the mean, the horizontal coloured line the median, the box the $25-75 \%$ percentiles, the length of the whiskers plot 10 and $90 \%$ of observed concentrations, and circles the outliers.

ber) seem to be in reasonably good agreement with those predicted for Europe by Backes et al. (2016). In contrast, the $0.59 \pm 0.30 \mu \mathrm{g} \mathrm{m}^{-3} \mathrm{NO}_{3}^{-}$concentration in $\mathrm{PM}_{2.5}$ measured over the warm season (including the April month characterized by predominant air mass buoyancy, and decreasing down to $0.44 \pm 0.12 \mu \mathrm{g} \mathrm{m}^{-3}$ if the April month is excluded) is lower than that predicted by Backes et al. (2016) (abundances as high as $0.8 \mu \mathrm{g} \mathrm{m}^{-3}$ over summer). Similar to the $\mathrm{NH}_{4}^{+}$case, this might reflect the susceptibility of $\mathrm{NO}_{3}^{-}$to be transferred to the gas phase over the warm season.

The $\mathrm{NO}_{3}^{-}$mass concentrations in both $\mathrm{PM}_{2.5}$ and $\mathrm{PM}_{10}$ had a statistically significant correlation with $\mathrm{RH}$, temperature, mixing layer depth, and particle loading (Table 3, detailed statistics in Table S4). However, it has to be observed that highly acidic aerosols expected over all seasons have the potential to affect the partitioning of $\mathrm{HNO}_{3}$ to the gas phase, producing low nitrate aerosol levels. Guo et al. (2015) also report low nitrate aerosol levels during summer. Moreover, $\mathrm{NO}_{3}^{-}$heterogeneous formation (i.e. condensation or absorption of $\mathrm{NO}_{2}$ in moist aerosols or $\mathrm{N}_{2} \mathrm{O}_{5}$ oxidation and $\mathrm{HNO}_{3}$ condensation) generally relates to $\mathrm{RH}$ and the partic- ulate loading (Wang et al., 2006; Ianniello et al., 2011). At the investigated site, this process might be of similar importance as the gas-particle conversion, which implies oxidation of precursor gases, such as $\mathrm{NO}_{x}$, to nitrate via $\mathrm{HNO}_{3}$ formation and involving photochemical processes. The high concentration of $\mathrm{NO}_{3}^{-}$during the cold season might also be caused by higher $\mathrm{NH}_{3}$ atmospheric levels from yet unaccounted sources, which could neutralize gas-phase $\mathrm{H}_{2} \mathrm{SO}_{4}$ and $\mathrm{HNO}_{3}$ to produce ammonium salts (vide infra). Reactive nitrogen species are emitted to the atmosphere mainly in the forms of $\mathrm{NO}_{x}$ (from transport or power generation) and $\mathrm{NH}_{3}$ (agriculture). In Iasi, the animal husbandry sector (open and closed barns, manure storage or spreading) is most likely an important $\mathrm{NH}_{3}$ source. Moreover, the high $\mathrm{RH}$ observed in the cold season could offer suitable conditions for significant fractions of $\mathrm{HNO}_{3}$ and $\mathrm{NH}_{3}$ to be dissolved in humid particles, therefore enhancing particulate-phase $\mathrm{NO}_{3}^{-}$ and $\mathrm{NH}_{4}^{+}$(Pathak et al., 2009, 2011; Ianniello et al., 2010; Sun et al., 2010). From measurements performed in October 2004 in Beijing, China, Kai et al. (2007) also concluded 
that high $\mathrm{RH}$, stable atmosphere, and high $\mathrm{NH}_{3}$ levels can enhance transformation of $\mathrm{NO}_{x}$ into $\mathrm{NO}_{3}^{-}$.

Particulate $\mathrm{SO}_{4}^{2-}$ maxima are observable during both cold and warm seasons. However, the particulate $\mathrm{SO}_{4}^{2-}$ mass concentrations showed statistically significant correlation with the measured meteorological parameters only at a $68 \%$ confidence level (detailed statistics in Table S4). The data presented in Fig. 6c show that the seasonal trend of the monthly $\mathrm{SO}_{4}^{2-}$ mean mass concentrations is not as clear as that of $\mathrm{NO}_{3}^{-}$and $\mathrm{NH}_{4}^{+}$, which might suggest the occurrence of regional $\mathrm{SO}_{4}^{2-}$ sources as well (Wang et al., 2016). Moreover, high RH (in Iasi, especially during cold months) may aid the conversion of $\mathrm{SO}_{2}$ to $\mathrm{SO}_{4}^{2-}$ (Kadowaki, 1986), with a significant enhancement of $\mathrm{SO}_{4}^{2-}$ production rate in the aqueous phase (Sharma et al., 2007). However, the oxidation of $\mathrm{SO}_{2}$ to sulfate may be induced not only by $\mathrm{H}_{2} \mathrm{O}_{2}$ in the aqueous phase, but also by gas-phase radical hydroxyl (Vione et al., 2003). This issue can explain the PM sulfate maxima during the warm season because of higher sunlight irradiance and temperature (Stelson and Seinfeld, 1982; Stockwell and Calvert, 1983; Kadowaki, 1986; Wang et al., 2005).

The data reported in Table 3 and Fig. 6f show that particulate $\mathrm{NH}_{4}^{+}$(total) has a clear seasonal pattern with maxima during the cold and minima over the warm season, in agreement with reports at other European (Schwarz et al., 2012; Bressi et al., 2013; Tositti et al., 2014; Voutsa et al., 2014) or non-European sites (Sharma et al., 2007; Wang et al., 2016). This behaviour is opposite to that reported by Ianniello et al. (2011). The cold season maxima and warm season minima we observed can be due to the effect of variations in the mixing layer depth, combined with gas-phase transfer of $\mathrm{NH}_{4} \mathrm{NO}_{3}$ to $\mathrm{NH}_{3}$ and $\mathrm{HNO}_{3}$ as temperature increases. In our dataset, $\mathrm{NH}_{4}^{+}$(total) varied from 0.8 to $2.09 \mu \mathrm{g} \mathrm{m}^{-3}$, a much lower range than that reported by Meng et al. (2011) for a more polluted site (Beijing, China, with concentrations varying between 4.73 and $9.04 \mathrm{\mu g} \mathrm{m}^{-3}$ among various seasons). However, the data we measured in the cold season $\left(2.03 \pm 0.30 \mu \mathrm{g} \mathrm{m}^{-3}\right.$ over January, February, and December; $1.65 \pm 0.23 \mu \mathrm{g} \mathrm{m}^{-3}$ over January, February, March, October, November, and December) seem to be in reasonable agreement with those predicted for Europe by Backes et al. (2016). In contrast, the $0.90 \pm 0.09 \mu \mathrm{g} \mathrm{m}^{-3} \mathrm{NH}_{4}^{+}$(total) measured concentration over the warm season is much lower than that predicted by Backes et al. (2016), and the discrepancy might actually reflect the limitation of the experimental measurement techniques concerning $\mathrm{NH}_{4} \mathrm{NO}_{3}$ volatility. Moreover, the $\mathrm{NH}_{4}^{+}$(total) mass concentration correlated significantly with $\mathrm{RH}$ and particle loading in both the $\mathrm{PM}_{2.5}$ and $\mathrm{PM}_{10}$ fractions, and it anticorrelated significantly with temperature and mixing layer depth (detailed statistics in Table S4). The $\mathrm{PM}_{2.5}$ fraction also showed statistically significant correlation with the mixing depth (Pearson coefficient higher than 0.67, $p=0.016$ ). The seasonal variation in particulate $\mathrm{NH}_{4}^{+}$(total) especially follows that of particulate $\mathrm{NO}_{3}^{-}$and $\mathrm{Cl}^{-}$, which would indicate that most probably $\mathrm{NH}_{4}^{+}$(total) largely originates from neutralization among $\mathrm{NH}_{3}, \mathrm{HNO}_{3}$, and $\mathrm{HCl}$ (Wang et al., 2006), or that the cited particulate species derive from similar gas-to-particle processes (Huang et al., 2010). Although in the present work gaseous $\mathrm{NH}_{3}$ was not measured, ISORROPIA-II runs predicted that the atmosphere was often in a gaseous ammonia-rich state, independent of the RH values $\left(\left[\mathrm{NH}_{3}\right] /\left(\left[\mathrm{HNO}_{3}\right]+[\mathrm{HCl}]\right) \gg 1\right)$.

At the investigated site, $\mathrm{C}_{2} \mathrm{O}_{4}^{2-}$ and $\mathrm{SO}_{4}^{2-}$ show similar behaviour and the $\mathrm{C}_{2} \mathrm{O}_{4}^{2-}$ maxima during summer may suggest photochemical and/or biogenic contributions to its abundance (Laongsri and Harrison, 2013). The $\mathrm{Na}^{+}$ion, tracer of sea salt or $\mathrm{NaCl}$ aerosols, shows higher concentrations during spring when one has a predominant long-range transport of air masses from the S-SE sector, with contributions from natural sources and especially sea spray aerosols from the Black Sea. Particulate $\mathrm{K}^{+}$mass concentrations also show a clear seasonal pattern, with higher values during the cold season compared to the warm season (Fig. 6e). This phenomenon could be due to increased wood burning combined with a limited mixing layer depth. However, particulate $\mathrm{K}^{+}$ mass concentrations also had some maxima when one expects intense agricultural biomass burning for field clearing (i.e. April, July, and September). The $\mathrm{K}^{+}$mass concentrations follow a pattern similar to $\mathrm{Cl}^{-}$(Pearson coefficient of $0.79, p=0.002$ ) but a different one compared to $\mathrm{SO}_{4}^{2-}$. Therefore, we suggest that intense wood burning may be a common source for $\mathrm{K}^{+}$and $\mathrm{Cl}^{-}$species in the study area (Christian et al., 2010; Akagi et al., 2011).

High mass concentrations of $\mathrm{Ca}^{2+}$ and $\mathrm{Mg}^{2+}$ (with $\mathrm{Mg}^{2+}$ shown in Table 3 but not in Fig. 6), as soil or dust tracers, were observed especially during spring and summer. Over these seasons, lower precipitation frequency and high wind speed contribute to the observed behaviour. During the cold season, low wind speeds might prevent mineral dust resuspension and produce low values for these ions. However, $\mathrm{Mg}^{2+}$ and $\mathrm{Ca}^{2+}$ as mineral ions did not correlate with either $\mathrm{PM}_{2.5}$ or $\mathrm{PM}_{10}$, which suggests that inorganic particles would be mainly produced by $\mathrm{NH}_{3}$-triggered secondary processes.

\subsubsection{Stoichiometry of $\left(\mathrm{NH}_{4}\right)_{2} \mathrm{SO}_{4}, \mathrm{NH}_{4} \mathrm{NO}_{3}$, and $\mathrm{NH}_{4} \mathrm{Cl}$}

Table 4 presents the correlation matrix (Pearson coefficients) for the major ionic species $\left(\mathrm{Cl}^{-}, \mathrm{NO}_{3}^{-}, \mathrm{SO}_{4}^{2-}, \mathrm{CH}_{3} \mathrm{COO}^{-}\right.$, $\mathrm{HCOO}^{-}, \mathrm{C}_{2} \mathrm{O}_{4}^{2-}, \mathrm{HCO}_{3}^{-}, \mathrm{Na}^{+}, \mathrm{NH}_{4}^{+}$(total), $\mathrm{K}^{+}, \mathrm{Mg}^{2+}$, $\mathrm{Ca}^{2+}$ ) in $\mathrm{PM}_{2.5}$, for both the cold (Table 4a) and the warm seasons (Table 4b). Despite similar correlations in $\mathrm{PM}_{10}$ as well, $\mathrm{PM}_{2.5}$ was selected for the correlation matrix analysis because of higher representativeness. For the cold season there are significant correlations (at the $99.9 \%$ confidence level) among many chemical pairs, suggesting an important occurrence of $\left(\mathrm{NH}_{4}\right)_{2} \mathrm{SO}_{4}, \mathrm{NH}_{4} \mathrm{NO}_{3}$, and $\left(\mathrm{NH}_{4}\right)_{2} \mathrm{C}_{2} \mathrm{O}_{4}$. In 
Table 4. Correlation matrix (Pearson coefficients) for major ionic species $\left(\mathrm{Cl}^{-}, \mathrm{NO}_{3}^{-}, \mathrm{SO}_{4}^{2-}, \mathrm{CH}_{3} \mathrm{COO}^{-}, \mathrm{HCOO}^{-}, \mathrm{C}_{2} \mathrm{O}_{4}^{2-}, \mathrm{HCO}_{3}^{-}, \mathrm{Na}^{+}\right.$, $\mathrm{NH}_{4}^{+}$(total), $\mathrm{K}^{+}, \mathrm{Mg}^{2+}, \mathrm{Ca}^{2+}$ ) in fine aerosol particles from Iasi, north-eastern Romania, for both cold (a) and warm (b) seasons. Bold font reflects statistical significant correlation at the $99.9 \%$ confidence level.

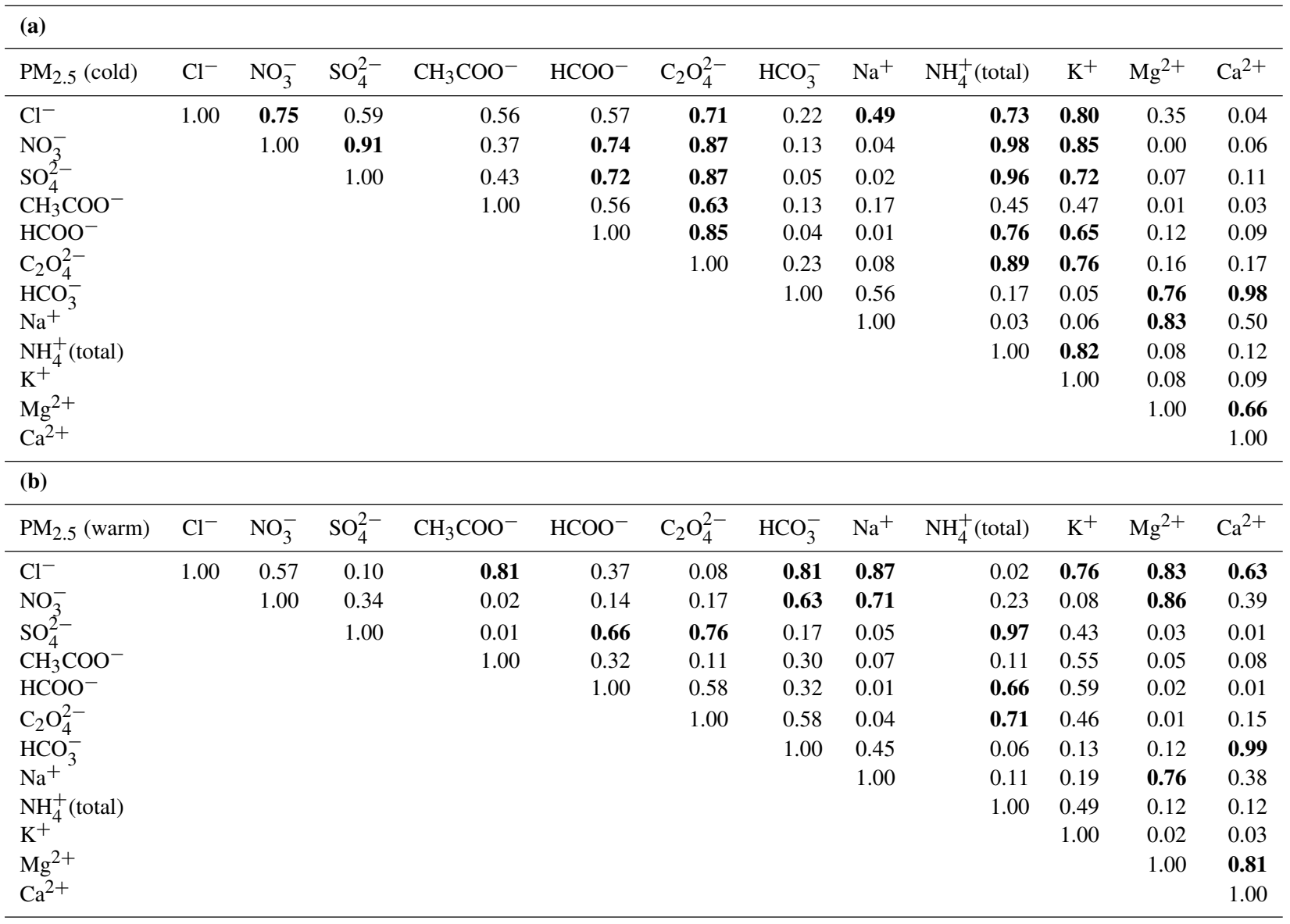

the warm season, $\left(\mathrm{NH}_{4}\right)_{2} \mathrm{SO}_{4}, \mathrm{Mg}\left(\mathrm{NO}_{3}\right)_{2}$, and $\mathrm{NaCl}$ seem to be the most important. However, $\mathrm{Ca}\left(\mathrm{HCO}_{3}\right)_{2}$ might play a role during both cold and warm seasons. Over the cold season, $\mathrm{K}^{+}$shows statistically significant correlation with many inorganic $\left(\mathrm{NO}_{3}^{-}, \mathrm{Cl}^{-}\right.$, and $\left.\mathrm{SO}_{4}^{2-}\right)$ and organic $\left(\mathrm{HCOO}^{-}\right.$and $\mathrm{C}_{2} \mathrm{O}_{4}^{2-}$ ) anions, thereby suggesting that at least some of these species might have common biomass burning sources (Ianniello et al., 2011, and references therein). However, in the case of $\mathrm{SO}_{4}^{2-}$ and $\mathrm{NO}_{3}^{-}$the most likely explanation would rather be the use of both coal and wood for burning, as well as the effect of the mixing layer depth.

In the ambient atmosphere, inorganic ammonium salts such as $\mathrm{NH}_{4} \mathrm{HSO}_{4},\left(\mathrm{NH}_{4}\right)_{2} \mathrm{SO}_{4}, \mathrm{NH}_{4} \mathrm{NO}_{3}$, and $\mathrm{NH}_{4} \mathrm{Cl}$ are known to be produced by gas-to-particle conversion processes. In the present work, from the ionic balance analysis the $\mathrm{NH}_{4}^{+}$ion was assigned as the most critical parameter in the chemical composition analysis of aerosol particles (with 274 analysed samples, i.e. about one-quarter of the total, being highly deficient in cations). Figure $7 \mathrm{a}$, b present the relationship between the molar concentrations of fine- particulate $\mathrm{NH}_{4}^{+}$(i.e. from raw IC data and also in the total form estimated under the assumptions from Arsene et al., 2011) and that of particulate $\mathrm{SO}_{4}^{2-}$ for both the cold (Fig. 7a) and warm (Fig. 7b) seasons. Correlations between particulate $\mathrm{NH}_{4}^{+}$and $\mathrm{SO}_{4}^{2-}$ are statistically significant in both cases (detailed statistics in Table S5).

During cold and warm seasons, the $\left[\mathrm{NH}_{4}^{+}\right] /\left(2 \times\left[\mathrm{SO}_{4}^{2-}\right]\right)$ molar ratio was either $\sim 1$ (raw IC data) or $\left(\mathrm{NH}_{4}^{+}\right.$(total) values) equal to 1.76 (cold season) and 1.02 (warm season). These data suggest the existence of enough $\mathrm{NH}_{3}$ for the complete neutralization of $\mathrm{H}_{2} \mathrm{SO}_{4}$, and also a predominance of particulate $\left(\mathrm{NH}_{4}\right)_{2} \mathrm{SO}_{4}$ in agreement with the observations of Ianniello et al. (2011). Moreover, as shown in Table 4, for particulate $\mathrm{SO}_{4}^{2-}$ and $\mathrm{NH}_{4}^{+}$(total) the correlation was statistically significant (with Pearson coefficients of $0.96, p<0.001$ for the cold season and $0.97, p<0.001$ for the warm season), thereby suggesting that $\left(\mathrm{NH}_{4}\right)_{2} \mathrm{SO}_{4}$ could be formed from $\mathrm{H}_{2} \mathrm{SO}_{4}(\mathrm{~g})$ and $\mathrm{NH}_{3}(\mathrm{~g})$ in either case. However, the 1.76 value for the $\left[\mathrm{NH}_{4}^{+}\right]($total $) /\left(2 \times\left[\mathrm{SO}_{4}^{2-}\right]\right)$ molar ratio during the cold season will indicate that there should still be 

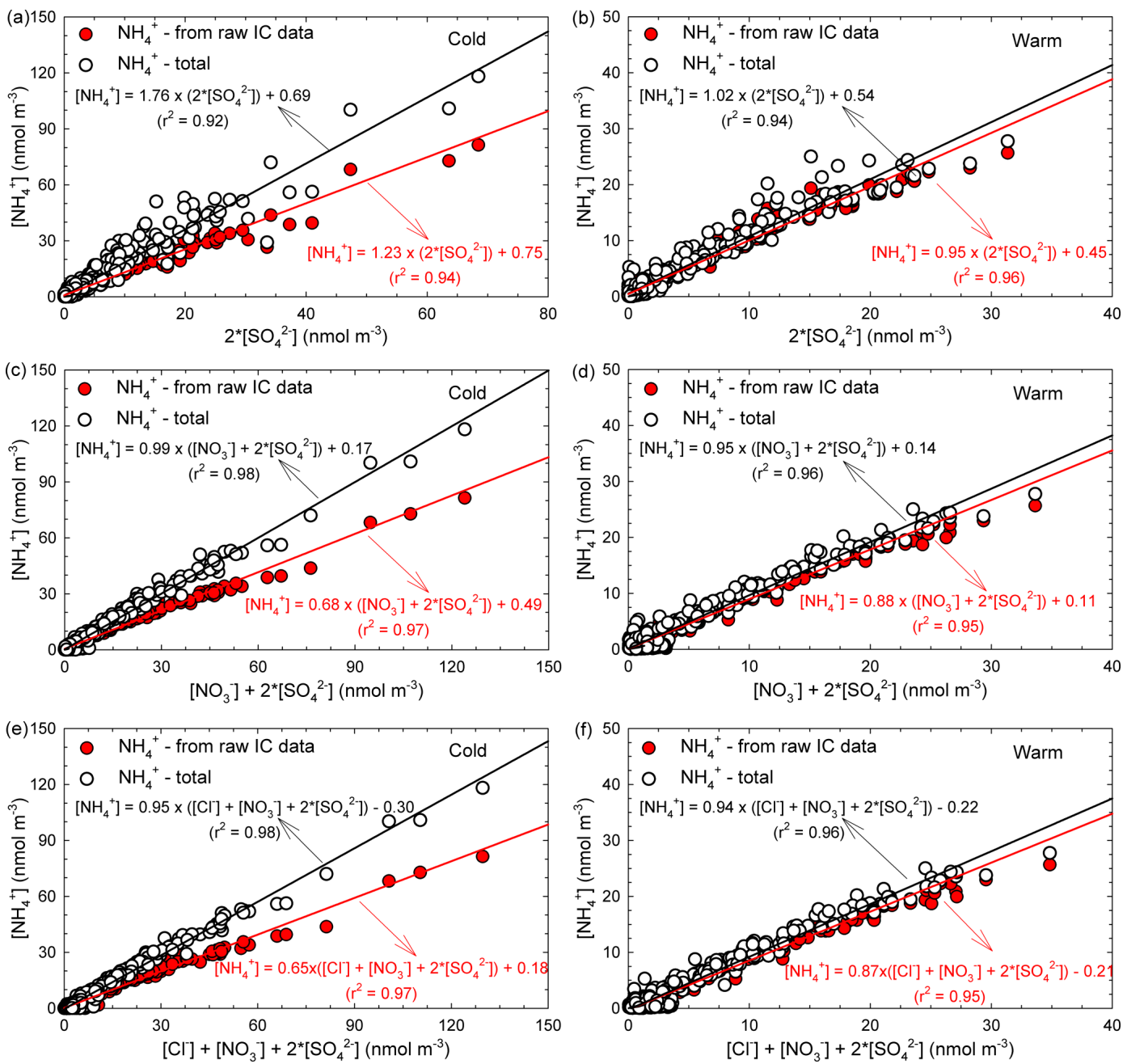

Figure 7. Regression analysis of the $\left[\mathrm{NH}_{4}^{+}\right]$vs. $\left(2 \times\left[\mathrm{SO}_{4}^{2-}\right]\right)(\mathbf{a}, \mathbf{b}),\left[\mathrm{NH}_{4}^{+}\right]$vs. $\left(\left[\mathrm{NO}_{3}^{-}\right]+2 \times\left[\mathrm{SO}_{4}^{2-}\right]\right)(\mathbf{c}, \mathbf{d})$, and $\left[\mathrm{NH}_{4}^{+}\right]$vs. $\left(\left[\mathrm{Cl}^{-}\right]+\left[\mathrm{NO}_{3}^{-}\right]+2 \times\left[\mathrm{SO}_{4}^{2-}\right]\right)(\mathbf{e}, \mathbf{f})$ dependences specific to $\mathrm{PM}_{2.5}$ particles.

particulate $\mathrm{NH}_{4}^{+}$potentially available for combination with other anions (or the existence of enough excess ammonia to neutralize acidic species such as $\mathrm{HNO}_{3}$ and $\mathrm{HCl}$ ). Zhao et al. (2016) report a $\left[\mathrm{NH}_{4}^{+}\right] /\left(2 \times\left[\mathrm{SO}_{4}^{2-}\right]\right)$ molar ratio of $1.54\left(R^{2}=0.63\right)$, indicating the complete neutralization of $\mathrm{H}_{2} \mathrm{SO}_{4}$ and a predominance of $\left(\mathrm{NH}_{4}\right)_{2} \mathrm{SO}_{4}$ in sulfate salts during the cold season.

Unfortunately, at present, no measured $\mathrm{NH}_{3}$ values are available for the site of interest but it is still believed that, in the atmosphere of Iasi, sufficient gas-phase $\mathrm{NH}_{3}$ occurs to promote both the homogeneous and heterogeneous formation of nitrate salts in the collected aerosol particles. The $\mathrm{NH}_{4} \mathrm{NO}_{3}$ formation routes might involve either the homogeneous reaction between gaseous $\mathrm{HNO}_{3}$ and $\mathrm{NH}_{3}$ (Ianniello et al., 2011) or the heterogeneous reaction between $\mathrm{NH}_{3}$ and the products formed upon hydrolysis of $\mathrm{N}_{2} \mathrm{O}_{5}$ that could be present on the surface of the pre-existing moist aerosols under relatively high humidity (Pathak et al., 2011; Shon et al.,
2013). Actually, gaseous $\mathrm{NH}_{3}$ can influence both the inorganic ions and the aqueous-phase $\mathrm{H}^{+}$distribution in aerosols. The concentration of $\mathrm{H}^{+}$in aqueous aerosols is mainly determined by the balance of the acidic ionic components with the basic ones. During both cold and warm seasons, about half or slightly more than half of the collected samples were found to be alkaline with $\mathrm{pH}$ values fluctuating between 7 and 8 . The remaining samples were acidic and with $\mathrm{pH}$ values ranging mainly from 1 to 3 . Zhao et al. (2016) report that, on average, a $+25 \%$ perturbation in the $\mathrm{NH}_{3}$ level could lead to a 0.14 unit $\mathrm{pH}$ increase, and a $-25 \%$ perturbation could cause a 0.23 unit $\mathrm{pH}$ decrease. They concluded that sufficient $\mathrm{NH}_{3}$ was frequently present in the wintertime atmosphere, and also that the fine collected particulates were almost fully neutralized by $\mathrm{NH}_{3}$.

Figure $7 \mathrm{c}, \mathrm{d}, \mathrm{e}, \mathrm{f}$ show the relationships between the fineparticulate molar concentrations of (i) $\mathrm{NH}_{4}^{+}$and the sum of $\mathrm{SO}_{4}^{2-}$ and $\mathrm{NO}_{3}^{-}$(Fig. 7c, d), and (ii) $\mathrm{NH}_{4}^{+}$and the sum of 
$\mathrm{SO}_{4}^{2-}, \mathrm{NO}_{3}^{-}$, and $\mathrm{Cl}^{-}$(Fig. 7e, f), for both cold and warm seasons. From details given in Fig. 7c, d, e, $\mathrm{f}$ it can be easily observed that $\mathrm{NH}_{4}^{+}$, with both calculation methods (IC and total), was in deficit over the cold and warm seasons. Under these circumstances, it is believed that both particulate $\mathrm{NO}_{3}^{-}$and $\mathrm{Cl}^{-}$could be associated with other alkaline species or be part of acidic aerosol. Because the neutralizing capacity of $\mathrm{NH}_{4}^{+}$toward $\mathrm{SO}_{4}^{2-}, \mathrm{NO}_{3}^{-}$and $\mathrm{Cl}^{-}$acidic species might give a rough indication on the potential particle acidity (Li et al., 2015); from Fig. 7c, d, e, f it is quite clear that at the study site, if $\mathrm{NH}_{4}^{+}$derived from raw IC data is used, the neutralization ratios in the investigated particles are less than unity. This suggests that the atmospheric particles are most likely acidic, and also that a more complex chemistry involving the $\mathrm{HNO}_{3}$ and $\mathrm{HCl}$ species is ongoing. However, when $\mathrm{NH}_{4}^{+}$(total) is used, the neutralization ratio approaches 1 and suggests a possibly complete neutralization of particle acidity. From details in Fig. 7e, $\mathrm{f}$ it can be easily seen that actually the available $\mathrm{NH}_{4}^{+}$is not enough to compensate for other species. However, it should be noted that $\mathrm{Cl}^{-}$ does not significantly influence the neutralization of particle acidity. In a study performed by Zhao et al. (2016) the authors reported a $\left[\mathrm{NH}_{4}^{+}\right] /\left(2 \times\left[\mathrm{SO}_{4}^{2-}\right]+\left[\mathrm{NO}_{3}^{-}\right]\right)$molar ratio of $0.86\left(R^{2}=0.78\right)$ and an $\left[\mathrm{NH}_{4}^{+}\right] /\left(2 \times\left[\mathrm{SO}_{4}^{2-}\right]+\left[\mathrm{NO}_{3}^{-}\right]+\right.$ $\left.\left[\mathrm{Cl}^{-}\right]\right)$molar ratio of $0.60\left(R^{2}=0.86\right)$. Details presented in Fig. 7c, d clearly show that when $\mathrm{NH}_{4}^{+}$(total) is taken into account, a complete neutralization of $\mathrm{H}_{2} \mathrm{SO}_{4}$ and $\mathrm{HNO}_{3}$ can be achieved during the cold season (Fig. 7c). In contrast, during the warm season (Fig. 7d) the molar ratio is slightly lower than 1 (i.e. 0.95). According to Seinfeld and Pandis (1998), during the warm season the high temperature and the low $\mathrm{RH}$ would be favourable for $\mathrm{NH}_{4}^{+}$to reach a minimum concentration because it is mainly transformed into $\mathrm{NH}_{3}$. Actually, temperature values above $25^{\circ} \mathrm{C}$, such as those often encountered at the investigated site over the warm season, are known to prevent formation of particulate $\mathrm{NH}_{4} \mathrm{NO}_{3}$ (Adams et al., 1999). Under these circumstances, a considerable decrease in the $\left[\mathrm{NH}_{4}^{+}\right]($total $) /\left(\left[\mathrm{NO}_{3}^{-}\right]+2 \times\left[\mathrm{SO}_{4}^{2-}\right]\right)$ molar ratio is to be expected during the warm season. The cold season temperature and $\mathrm{RH}$ at the investigated site were, respectively, $5.3 \pm 3.9^{\circ} \mathrm{C}$ and $(65.3 \pm 12.8) \%$. Coherently, the data presented in Table 4 show that the $\left(\mathrm{NO}_{3}^{-}\right.$, $\mathrm{NH}_{4}^{+}$(total)) pair has a significant correlation (Pearson coefficient of $0.98, p<0.001$ ) only during the cold season, while during the warm season (temperature and $\mathrm{RH}$ of, respectively, $18.9 \pm 3.8^{\circ} \mathrm{C}$ and $40.5 \pm 7.7 \%$ ) the correlation is very poor as increasing temperature and decreasing RH limit the production of the $\mathrm{NH}_{4} \mathrm{NO}_{3}$ aerosol (Matsumoto and Tanaka, 1996; Utsunomiya and Wakamatsu, 1996; Alastuey et al., 2004).

In the atmosphere, both $\mathrm{H}_{2} \mathrm{SO}_{4}$ and $\mathrm{HNO}_{3}$ are known to compete for the reaction with $\mathrm{NH}_{3}$ to form $\left(\mathrm{NH}_{4}\right)_{2} \mathrm{SO}_{4}$ and $\mathrm{NH}_{4} \mathrm{NO}_{3}$. As presented in Sect. 3.2.2, at the investigated site a reduction in both in $\mathrm{NO}_{3}^{-}$and $\mathrm{SO}_{4}^{2-}$ was observed over the warm season and this may cause a further increase in gasphase $\mathrm{NH}_{3}$. It is also interesting to observe that the reaction rate constant of $\left(\mathrm{NH}_{4}\right)_{2} \mathrm{SO}_{4}$ aerosol formation is similar to the rate constant of $\mathrm{NH}_{4} \mathrm{NO}_{3}$ formation (Harrison and Kitto, 1992; Pandolfi et al., 2012; Behera et al., 2013), and both are much higher than the rate constant between $\mathrm{NH}_{3}$ and $\mathrm{HCl}$ (Behera and Sharma, 2012). This issue probably dictates the competition of any of the particulate $\mathrm{SO}_{4}^{2-}, \mathrm{NO}_{3}^{-}$, and $\mathrm{Cl}^{-}$for the available $\mathrm{NH}_{4}^{+}$. Usually, when a sufficient amount of $\mathrm{NH}_{3}$ is available for neutralization of $\mathrm{H}_{2} \mathrm{SO}_{4}$ and $\mathrm{HNO}_{3}$, fine-mode $\left(\mathrm{NH}_{4}\right)_{2} \mathrm{SO}_{4}$ and $\mathrm{NH}_{4} \mathrm{NO}_{3}$ will be formed via Reactions (R1) (Cziczo et al., 1997; Zhang et al., 2015) and (R2) (Fountoukis and Nenes, 2007; Zhang et al., 2015).

$$
\begin{aligned}
& 2 \mathrm{NH}_{3(\mathrm{~g})}+\mathrm{H}_{2} \mathrm{SO}_{4(\mathrm{aq})} \rightleftharpoons\left(\mathrm{NH}_{4}\right)_{2} \mathrm{SO}_{4(\mathrm{aq})} \\
& \mathrm{NH}_{3(\mathrm{~g})}+\mathrm{HNO}_{3(\mathrm{~g})} \rightleftharpoons \mathrm{NH}_{4} \mathrm{NO}_{3(\mathrm{~s})}
\end{aligned}
$$

In contrast, in $\mathrm{NH}_{3}$-limited environments, coarse-mode $\mathrm{NO}_{3}^{-}$ is formed through Reaction (R3) involving $\mathrm{Mg}^{2+}$ (but not $\left.\mathrm{Ca}^{2+}\right)$ :

$$
\begin{aligned}
\mathrm{MgCO}_{3(\mathrm{aq})} & +2 \mathrm{HNO}_{3(\mathrm{~g})} \rightleftharpoons \mathrm{Mg}\left(\mathrm{NO}_{3}\right)_{2(\mathrm{~s})} \\
& +\mathrm{H}_{2} \mathrm{O}+\mathrm{CO}_{2(\mathrm{~g})} .
\end{aligned}
$$

During the warm season, however, higher concentrations of $\left(\mathrm{NH}_{4}\right)_{2} \mathrm{SO}_{4}$ compared to $\mathrm{NH}_{4} \mathrm{NO}_{3}$ are expected because $\left(\mathrm{NH}_{4}\right)_{2} \mathrm{SO}_{4}$ is less volatile than $\mathrm{NH}_{4} \mathrm{NO}_{3}$ (Utsunomiya and Wakamatsu, 1996). Moreover, $\mathrm{NH}_{4} \mathrm{NO}_{3}$ will be formed only when excess $\mathrm{NH}_{3}$ is available to react with $\mathrm{HNO}_{3}$. A modelling study by Backes et al. (2016) suggests that a reduction of $\mathrm{NH}_{3}$ emissions by $50 \%$ may lead to a $24 \%$ reduction of the total $\mathrm{PM}_{2.5}$ concentrations in north-western Europe, mainly due to reduced formation of $\mathrm{NH}_{4} \mathrm{NO}_{3}$. However, the $\mathrm{NH}_{3}$ concentration in the atmosphere over Europe seems to be high enough to saturate the reaction forming $\left(\mathrm{NH}_{4}\right)_{2} \mathrm{SO}_{4}$ particles, even in a scenario of reduced $\mathrm{NH}_{3}$ levels, while on the contrary it is not high enough to saturate the reaction with $\mathrm{HNO}_{3}$ to form $\mathrm{NH}_{4} \mathrm{NO}_{3}$ particles. A reduced formation of $\mathrm{NH}_{4} \mathrm{NO}_{3}$ particles may lead to an increase in gasphase $\mathrm{HNO}_{3}$ during winter. In our study, results from the ISORROPIA-II thermodynamic model foresee an increase in gas-phase $\mathrm{HNO}_{3}$ at higher $\mathrm{RH}$ values during the cold season. Higher levels of gas-phase $\mathrm{HNO}_{3}$ may increase its condensation onto existing particles such as sodium chloride $(\mathrm{NaCl})$, and the replacement of $\mathrm{Cl}^{-}$with $\mathrm{NO}_{3}^{-}$may enhance the concentration of $\mathrm{HCl}$ in the atmosphere (similar processes are described in Arsene et al., 2011).

In the atmosphere, additional non-volatile species containing nitrate and chloride might also be present; thus we investigated the potential of fine-particulate $\mathrm{NO}_{3}^{-}$and $\mathrm{Cl}^{-}$to be chemically bound to $\mathrm{Ca}^{2+}, \mathrm{Mg}^{2+}, \mathrm{K}^{+}$, or $\mathrm{Na}^{+}$. The free $\mathrm{NO}_{3}^{-}$and $\mathrm{Cl}^{-}$concentrations, defined as the fractions of excess nitrate and chloride that are not bound to alkali or alkaline earth metals, were estimated for both 
the cold and warm seasons according to the concept described in Ianniello et al. (2011). Zero or negative values of free $\mathrm{NO}_{3}^{-}$and $\mathrm{Cl}^{-}$imply that $\mathrm{NH}_{4} \mathrm{NO}_{3}$ and $\mathrm{NH}_{4} \mathrm{Cl}$ are not present. Estimated free $\mathrm{NO}_{3}^{-}$and $\mathrm{Cl}^{-}$concentrations showed similar contributions in both the $\mathrm{PM}_{2.5}$ and $\mathrm{PM}_{10}$ fractions. Over the cold season we calculated $(6.5 \pm 7.9) \times 10^{-3} \mu \mathrm{mol} \mathrm{m}^{-3}\left(0.4 \pm 0.5 \mu \mathrm{g} \mathrm{m}^{-3}\right)$ for $\mathrm{NO}_{3}^{-}$, and negative values for free $\mathrm{Cl}^{-}$; over the warm season we had $(1.6 \pm 1.8) \times 10^{-3} \mu \mathrm{mol} \mathrm{m}^{-3}\left(0.1 \pm 0.1 \mu \mathrm{g} \mathrm{m}^{-3}\right)$ for $\mathrm{NO}_{3}^{-}$, and again negative values for free $\mathrm{Cl}^{-}$(data provided as mean $\pm \mathrm{SD}$ ). This result suggests the potential presence of $\mathrm{NH}_{4} \mathrm{NO}_{3}$, especially during the cold season, but it excludes the occurrence of $\mathrm{NH}_{4} \mathrm{Cl}$. During the cold season, particulate $\mathrm{NO}_{3}^{-}$did not show correlation with either $\mathrm{Ca}^{2+}$ or $\mathrm{Mg}^{2+}$, but it showed significant correlation with $\mathrm{K}^{+}(r=0.85$, $p<0.001$; see Table 4), which indicates the possible formation of the non-volatile $\mathrm{KNO}_{3}$ salt along with $\mathrm{NH}_{4} \mathrm{NO}_{3}$. Over the warm season, fine-particulate $\mathrm{NO}_{3}^{-}$did not show correlation with $\mathrm{K}^{+}$, but it showed significant correlation with $\mathrm{Na}^{+}$and $\mathrm{Mg}^{2+}$ (respectively, $r=0.71, p<0.001$ and $r=0.86, p<0.001$ ), indicating possible formation of nonvolatile $\mathrm{NaNO}_{3}$ and $\mathrm{Mg}\left(\mathrm{NO}_{3}\right)_{2}$ but not of $\mathrm{Ca}\left(\mathrm{NO}_{3}\right)_{2}$ salts. Moreover, in the warm season the fine-particulate $\mathrm{NO}_{3}^{-}$ also showed statistically significant correlation with $\mathrm{HCO}_{3}^{-}$ $(r=0.63, p<0.001)$, which suggests a prevalence of particulate $\mathrm{NO}_{3}^{-}$formation via the mineral route over the homogeneous reactions. The interaction between $\mathrm{NO}_{3}^{-}$and $\mathrm{Mg}^{2+}$ could increase in importance during the warm season because, as $\mathrm{NH}_{4}^{+}$is not available, neutralization of $\mathrm{HNO}_{3}$ could occur on coarse soil particles rich in $\mathrm{Mg}^{2+}$ (Matsumoto and Tanaka, 1996; Utsunomiya and Wakamatsu, 1996; Alastuey et al., 2004).

From the literature it is known that species such as $\left(\mathrm{NH}_{4}\right)_{2} \mathrm{SO}_{4}$ and $\mathrm{NH}_{4} \mathrm{HSO}_{4}$, at room temperature, uptake water (deliquesce) at RH values of, respectively, $(79 \pm 1) \%$ and $39 \%$ (Cziczo et al., 1997). The $\left(\mathrm{NH}_{4}\right)_{2} \mathrm{SO}_{4}$ aerosol particles might remain in metastable or supersaturated state liquid phase until a very low RH (crystallization point, $\mathrm{RH}$ around $33 \%$ ) is reached (only thereafter a solid might be formed). In contrast, for $\mathrm{NH}_{4} \mathrm{HSO}_{4}$ it has been shown that the solid phase is difficult to form. In the present work, it is very likely that only over July (RH of $32.95 \%$ ), August (RH of $37.12 \%$ ), and September ( $\mathrm{RH}$ of $31.56 \%$ ) could the formation of solid $\left(\mathrm{NH}_{4}\right)_{2} \mathrm{SO}_{4}$ or $\mathrm{NH}_{4} \mathrm{HSO}_{4}$ occur.

Pure $\mathrm{NH}_{4} \mathrm{NO}_{3}$ deliquesces at $62 \% \mathrm{RH}$ and there is suggestion that sometimes even at $8 \% \mathrm{RH}$ the crystallization point is not reached (Dougle et al., 1998). According to suggestions from the literature, only during months when the ambient RH is lower than the RH at deliquescence (RHD), is the $\mathrm{NH}_{4} \mathrm{NO}_{3}$ considered as a solid (Seinfeld and Pandis, 1998). In the present work, from March to October the ambient $\mathrm{RH}$ was always lower than the RHD and $\mathrm{NH}_{4} \mathrm{NO}_{3}$ could thus be assumed to be in equilibrium with the solid phase. Within all the other months, from the estimated RHD values there is the possibility that $\mathrm{NH}_{4} \mathrm{NO}_{3}$ is in equilibrium with the aqueous phase and deliquescent particles. However, in the investigated site, solid $\mathrm{NH}_{4} \mathrm{NO}_{3}$ could be formed almost over the entire year due to either the very complex chemical composition of the collected particles or the abundant contribution of organic carbon to the particle mass concentration (Dougle et al., 1998). Formation of $\mathrm{NH}_{4} \mathrm{NO}_{3}$ over the warm season has also been reported by Ianniello et al. (2011) but under different conditions. For deliquesced particles it is suggested that most of the fine-particulate $\mathrm{NO}_{3}^{-}$occurs as an internal mixture with $\mathrm{SO}_{4}^{2-}$, and also that $\mathrm{HNO}_{3}$ can easily be absorbed into the droplets (Huang et al., 2010). In specific circumstances, the fine-particulate $\mathrm{NO}_{3}^{-}$can be formed from $\mathrm{HNO}_{3}$ and $\mathrm{NH}_{3}$ through heterogeneous reactions on fully neutralized fine-particulate $\mathrm{SO}_{4}^{2-}$, which is abundant in urban areas (Stockwell et al., 2000). In the present work, a statistically significant correlation between $\mathrm{SO}_{4}^{2-}$ and $\mathrm{NO}_{3}^{-}$ was observed during the cold season in the $\mathrm{PM}_{2.5}$ fraction $(r=0.91, p<0.001)$. High concentrations of $\mathrm{NO}_{3}^{-}$were found in the presence of elevated $\mathrm{RH}$ levels (significant correlation: $r=0.84, p<0.001$ ), while $\mathrm{SO}_{4}^{2-}$ concentrations were high over the entire $\mathrm{RH}$ range (non-significant correlation: $r=0.44, p=0.177)$. These results can be interpreted as nitrate being produced on pre-existing sulfate aerosols, which could provide sufficient surface area and water content for the heterogeneous reactions to occur. Although the formation of fine-particulate $\mathrm{NO}_{3}^{-}$can take place via Reaction (R2), in particular circumstances and especially at high $\mathrm{RH}$ values, the amounts of the gaseous precursors such as $\mathrm{NH}_{3}$ and $\mathrm{HNO}_{3}$ may have relatively little influence on the fine-particulate $\mathrm{NO}_{3}^{-}$formation (Markovic et al., 2011).

The salt $\mathrm{NH}_{4} \mathrm{Cl}$ is known to be $2-3$ times more volatile than $\mathrm{NH}_{4} \mathrm{NO}_{3}$, as $\mathrm{HCl}$ is more volatile than $\mathrm{HNO}_{3}$. Moreover, at $\mathrm{RH}<75-85 \%$, particulate $\mathrm{NH}_{4} \mathrm{Cl}$ is in equilibrium with the gaseous compounds (Ianniello et al., 2011, and references therein). Coherently, during the cold season particulate $\mathrm{NH}_{4}^{+}$(total) showed a statistically significant correlation with particulate $\mathrm{Cl}^{-}$(Pearson coefficient of $0.73, p<0.001$ ), but during the warm season the correlation was very poor. Finally, only during the cold season were significant correlations between fine-particulate $\mathrm{Cl}^{-}$and $\mathrm{SO}_{4}^{2-}$ (Pearson coefficient of $0.59, p<0.001)$ and between fine-particulate $\mathrm{Cl}^{-}$and RH (Pearson coefficient of $0.71, p=0.010$ ) observed. Usually, high concentrations of fine-particulate $\mathrm{Cl}^{-}$ and $\mathrm{SO}_{4}^{2-}$ were found at high levels of $\mathrm{RH}(35-83 \%)$. Under these circumstances, the amount of gaseous precursors is believed to have relatively little influence on the formation of fine-particulate $\mathrm{Cl}^{-}$. If formed, $\mathrm{NH}_{4} \mathrm{Cl}$ is most probably generated from $\mathrm{HCl}$ and $\mathrm{NH}_{3}$ through heterogeneous reactions on neutralized sulfate particles. However, in the present work, estimation of free $\mathrm{Cl}^{-}$suggests that no $\mathrm{Cl}^{-}$was available to be bound with other chemical species (i.e. $\mathrm{NH}_{4}^{+}$) apart from alkali or alkaline earth metals, thereby excluding a significant occurrence of $\mathrm{NH}_{4} \mathrm{Cl}$ (especially over the warm season). 

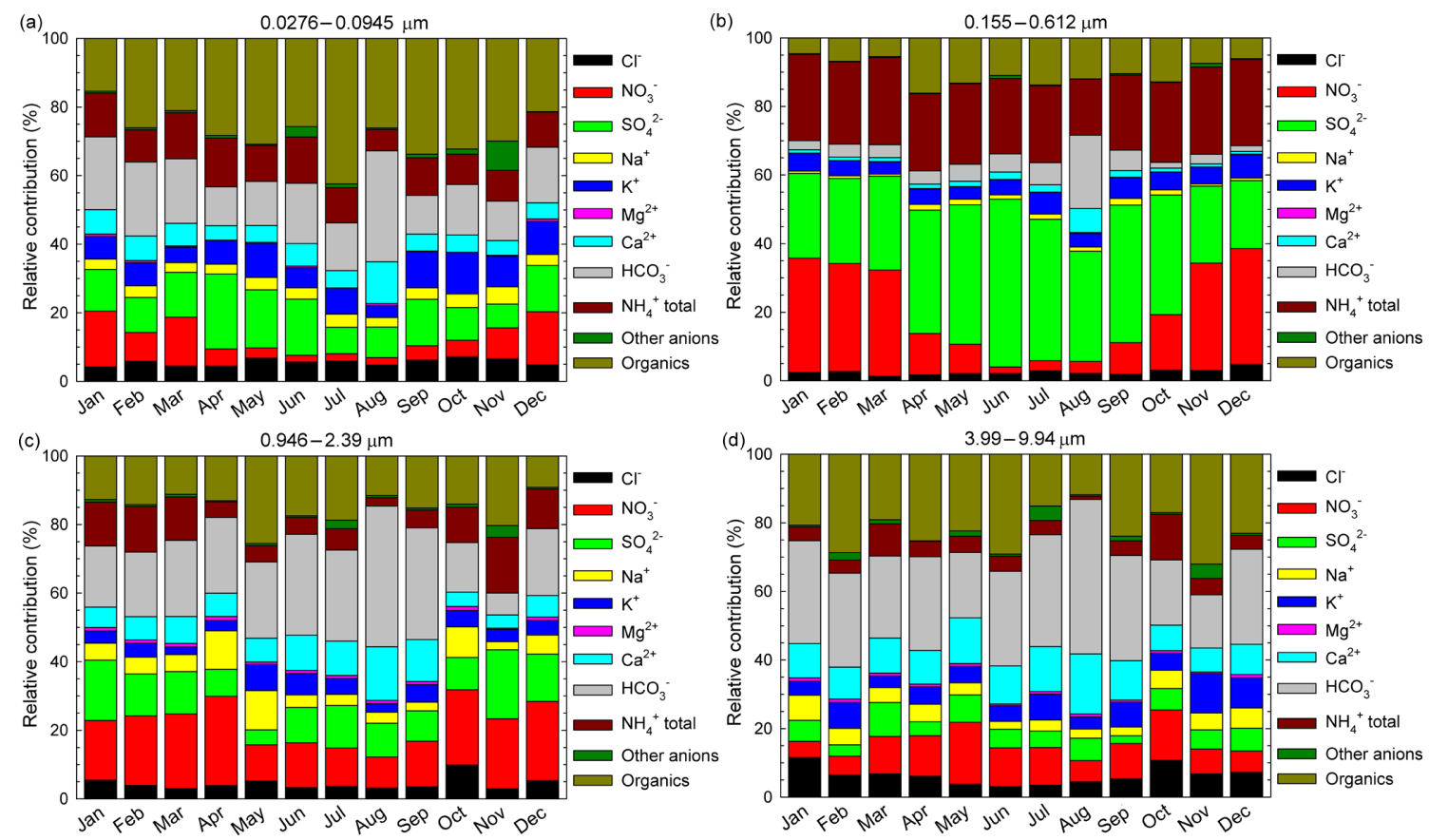

Figure 8. The relative contributions, as monthly averages, of identified and quantified water-soluble ions to total detected components in the

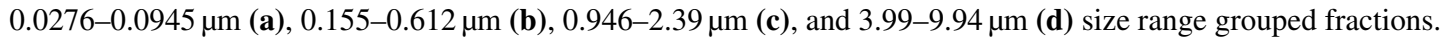

\subsection{Relative ionic contribution in size-resolved aerosol particles from Iasi and potential influence of long-range transport phenomena on particle size distribution}

Figure $8 \mathrm{a}, \mathrm{b}, \mathrm{c}, \mathrm{d}$ present, as monthly averages, the relative contributions of identified and quantified water-soluble ions to total detected components in fractions grouped in four stages, i.e. $0.0276-0.0945 \mu \mathrm{m}$ size range (Fig. 8a), 0.155$0.612 \mu \mathrm{m}$ size range (Fig. $8 \mathrm{~b}$ ), $0.946-2.39 \mu \mathrm{m}$ size range (Fig. 8c), and 3.99-9.94 $\mu \mathrm{m}$ size range (Fig. 8d). From details presented in Fig. 8a, for the 0.0276-0.0945 $\mu \mathrm{m}$ fraction there is an important contribution of formate, acetate, and oxalate that may actually indicate a possible important role of organic acids in secondary organic aerosol formation. Higher values of these components over the warm season may suggest an enhancement in the role of biogenic emission sources. Important contributions come from $\mathrm{SO}_{4}^{2-}, \mathrm{NH}_{4}^{+}$(total), $\mathrm{K}^{+}$, and even (unexpectedly high) $\mathrm{HCO}_{3}^{-}$. However, high particulate $\mathrm{HCO}_{3}^{-}$is also evident for the 0.946-2.39 $\mu \mathrm{m}$ (Fig. 8c) and 3.99-9.94 $\mu \mathrm{m}$ size range (Fig. $8 \mathrm{~d}$ ) fractions. The 0.155$0.612 \mu \mathrm{m}$ fraction (Fig. $8 \mathrm{~b}$ ) seems to be mainly constituted by $\mathrm{SO}_{4}^{2-}, \mathrm{NO}_{3}^{-}$, and $\mathrm{NH}_{4}^{+}$(total), with very small contributions from other ions.

The seasonal variation observed mainly for $\mathrm{SO}_{4}^{2-}$ and $\mathrm{NO}_{3}^{-}$might suggest an enhancement of photo-oxidative processes over the warm season. The 0.946-2.39 $\mu \mathrm{m}$ (Fig. 8c) and 3.99-9.94 $\mu \mathrm{m}$ size range (Fig. 8d) fractions have a nonhomogeneous chemical composition dominated mainly by
$\mathrm{HCO}_{3}^{-}, \mathrm{NO}_{3}^{-}$, and organics. Among all the analysed ions in the investigated period, in the $\mathrm{PM}_{10}$ fraction $\mathrm{SO}_{4}^{2-}$ was the most abundant with $(26.0 \pm 4.3) \%$, followed by $\mathrm{NO}_{3}^{-}$ $(26.0 \pm 10.7 \%), \mathrm{NH}_{4}^{+}$(total) $(15.0 \pm 3.4 \%)$, organics including acetate, formate, and oxalate $(12.2 \pm 3.7 \%)$, and $\mathrm{HCO}_{3}^{-}$ $(10 \pm 7.7 \%)$. Similarly, in the $\mathrm{PM}_{2.5}$ fraction $\mathrm{SO}_{4}^{2-}$ was again the most abundant $(28.9 \pm 5.6 \%)$ followed by $\mathrm{NO}_{3}^{-}$ $(19.6 \pm 12.1 \%), \mathrm{NH}_{4}^{+}$(total) $(16.6 \pm 3.2 \%)$, organics including acetate, formate, and oxalate $(11.4 \pm 4.0 \%)$, and $\mathrm{HCO}_{3}^{-}$ $(8.0 \pm 6.8 \%)$. In both the $\mathrm{PM}_{10}$ and $\mathrm{PM}_{2.5}$ fractions, the largest contribution of $\mathrm{SO}_{4}^{2-}$ was observed in June 2016 with, respectively, $(34.6 \pm 10.9 \%)$ and $(40.8 \pm 11.0 \%)$. During the cold season, particulate $\mathrm{SO}_{4}^{2-}$ and $\mathrm{NO}_{3}^{-}$contributions were, respectively, $(23.6 \pm 2.3 \%)$ and $(28.6 \pm 4.9 \%)$ for $\mathrm{PM}_{10}$ and $(25.5 \pm 2.9 \%)$ and $(30.1 \pm 5.8 \%)$ for $\mathrm{PM}_{2.5}$. During the warm season, the $\mathrm{SO}_{4}^{2-}$ and $\mathrm{NO}_{3}^{-}$contributions, were, respectively, $(28.5 \pm 4.7 \%)$ and $(10.1 \pm 4.8 \%)$ for $\mathrm{PM}_{10}$ and $(32.4 \pm 5.6 \%)$ and $(9.2 \pm 5.4 \%)$ for $\mathrm{PM}_{2.5}$. Wonaschutz et al. (2015) report $\mathrm{NO}_{3}^{-}$contributions of $31.3 \%$ during winter and $6.9 \%$ during summer for Vienna (Austria).

Particulate $\mathrm{Ca}^{2+}$ and $\mathrm{HCO}_{3}^{-}$, as dust tracer ions, contributed significantly, especially over the warm season $\left(43.8 \pm 11.2 \%\right.$ in $\mathrm{PM}_{10}$ and $37.8 \pm 12.3 \%$ in $\mathrm{PM}_{2.5}$ in $\mathrm{Au}-$ gust 2016), suggesting that $\mathrm{Ca}^{2+}$ and $\mathrm{HCO}_{3}^{-}$mostly originate from soil dust resuspension during the dry season. In 2016, spring was the season with predominant air masses undertaking long-range transport from the S-SE sector (see Fig. 1), thereby suggesting the presence of sea spray aerosols from the Black Sea or other marine areas. The highest contribu- 

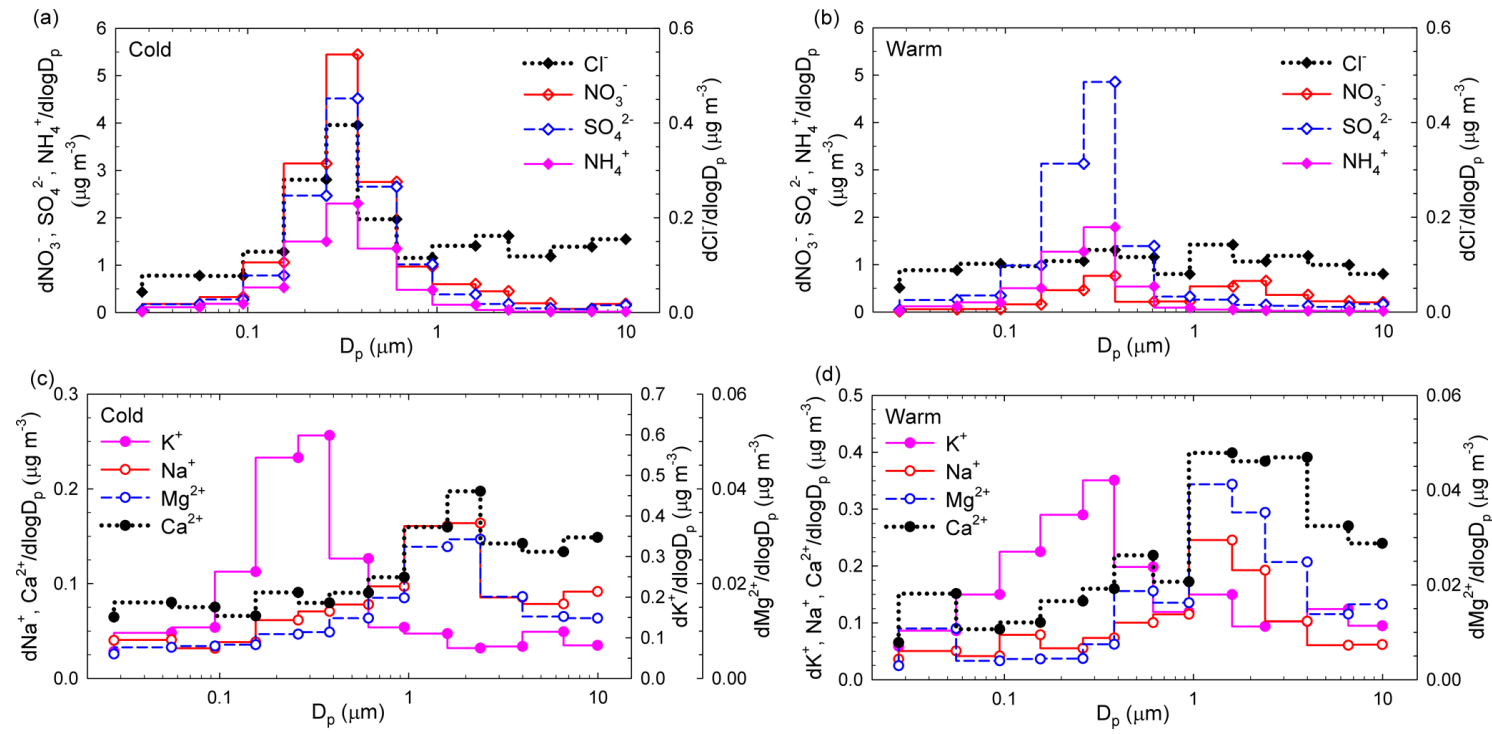

Figure 9. Size distributions of seasonal averaged mass concentrations for $\mathrm{Cl}^{-}, \mathrm{NO}_{3}^{-}, \mathrm{SO}_{4}^{2-}$, and $\mathrm{NH}_{4}^{+}(\mathbf{a}, \mathbf{b})$ and $\mathrm{K}^{+}, \mathrm{Na}^{+}, \mathrm{Mg}^{2+}$, and $\mathrm{Ca}^{2+}(\mathbf{c}, \mathbf{d})$ ions in atmospheric aerosols from Iasi, during both the cold season and the warm season, respectively.

tions from sea spray aerosol tracers (i.e. $\mathrm{Na}^{+}$and $\mathrm{Mg}^{2+}$; Masiol et al., 2012) were actually recorded in April (5.8\% for $\mathrm{Na}^{+}$and $0.7 \%$ for $\mathrm{Mg}^{2+}$ ). Although the most abundant ions are $\mathrm{SO}_{4}^{2-}, \mathrm{NO}_{3}^{-}$, and $\mathrm{NH}_{4}^{+}$(total), organics (including acetate, formate, and oxalate) might also bring significant contributions $\left((17.3 \pm 4.4) \%\right.$ in $\mathrm{PM}_{10}$ and $18.2 \pm 5.1 \%$ in $\mathrm{PM}_{2.5}$ in July 2016, much higher than that reported by Arsene et al., 2011, for Iasi). The difference might reflect either an inversion of the photochemistry taking place at the investigated location, or differences in the sampling efficiency between the two studies.

Figure $9 \mathrm{a}, \mathrm{b}, \mathrm{c}, \mathrm{d}$ show the size distributions of seasonal averaged mass concentrations for $\mathrm{Cl}^{-}, \mathrm{NO}_{3}^{-}, \mathrm{SO}_{4}^{2-}$, and $\mathrm{NH}_{4}^{+}$ (Fig. 9a, b) and $\mathrm{K}^{+}, \mathrm{Na}^{+}, \mathrm{Mg}^{2+}$, and $\mathrm{Ca}^{2+}$ (Fig. 9c, d). While during the cold season $\mathrm{NO}_{3}^{-}, \mathrm{SO}_{4}^{2-}, \mathrm{NH}_{4}^{+}$, and $\mathrm{K}^{+}$ reside mainly in the fine mode with maxima at $\sim 381 \mathrm{~nm}$, all the other ions (i.e. $\mathrm{Cl}^{-}, \mathrm{Na}^{+}, \mathrm{Mg}^{2+}, \mathrm{Ca}^{2+}$ ) have major contributions in the super-micron mode (maxima between 1.6 and $2.39 \mu \mathrm{m}$ ). Over the cold season, clear evidence was obtained of the occurrence of chloride in a bimodal distribution. During the warm season only $\mathrm{SO}_{4}^{2-}$ and $\mathrm{K}^{+}$presented clear maxima at $381 \mathrm{~nm}$, while all the other identified or quantified species had more important contributions in the super-micron mode. For $\mathrm{SO}_{4}^{2-}$, a larger modal diameter in the cold season compared to the warm season is most likely due to hygroscopic growth under high RH and/or to increased secondary aerosol production (lower temperatures facilitate condensation). Secondary aerosol mass from aqueous-phase reactions may also play a role (Wonaschutz et al., 2015). The maxima observed in the coarse mode could also be explained considering that heterogeneous chemistry on dust particles might act as a source for some particulate species (Wang et al., 2012).

While particulate $\mathrm{NO}_{3}^{-}$over the cold season presented monomodal distributions in the sub-micron size range ( $\max -$ ima at $381 \mathrm{~nm}$ ), over the warm season a second mode was observed with maxima in the $1.60-2.39 \mu \mathrm{m}$ size range. Such a size distribution suggests that $\mathrm{NO}_{3}^{-}$during the warm season is produced by adsorption of $\mathrm{HNO}_{3}$ on sea salt and soil particles (Park et al., 2004). According to Karydis et al. (2016), particulate $\mathrm{NO}_{3}^{-}$is not only associated with $\mathrm{NH}_{4}^{+}$in the fine mode. Light metal ions such as $\mathrm{Ca}^{2+}, \mathrm{Mg}^{2+}, \mathrm{Na}^{+}$, and $\mathrm{K}^{+}$, which mainly occur in the coarse mode, can be associated with $\mathrm{NO}_{3}^{-}$and affect its partitioning into the aerosol phase. Dust effects on the distribution of particulate species might include a decrease in fine-mode $\mathrm{NH}_{4}^{+}$and a shift of particulate $\mathrm{NO}_{3}^{-}$from the fine to the coarse mode (Wang et al., 2012). In addition, the presence of significant levels of $\mathrm{NO}_{3}^{-}$, $\mathrm{Cl}^{-}, \mathrm{Mg}^{2+}, \mathrm{Ca}^{2+}$, and $\mathrm{Na}^{+}$in the coarse fraction might suggest that $\mathrm{NO}_{3}^{-}$possibly originates upon reaction of $\mathrm{HNO}_{3}$ with $\mathrm{MgCO}_{3}, \mathrm{CaCO}_{3}$, or $\mathrm{NaCl}$. Similar patterns were identified in Vienna, Austria (Wonaschutz et al., 2015), and in Prague, Czech Republic (Schwarz et al., 2012). Significant amounts of particulate $\mathrm{NO}_{3}^{-}$formed upon reaction of $\mathrm{HNO}_{3}$ with $\mathrm{CaCO}_{3}$ on soil-derived particles have also been observed and reported (Yao et al., 2003; Sharma et al., 2007). Moreover, sea salt aerosols may also undergo chemical transformation of $\mathrm{NaCl}$ into $\mathrm{NaNO}_{3}$ during transport (Schwarz et al., 2012).

The size distributions of particulate $\mathrm{K}^{+}$reflect the occurrence of one dominant fine mode (with maxima at $381 \mathrm{~nm}$ ) during both the cold and the warm seasons and of a second, less important mode during the warm season (with maxima 

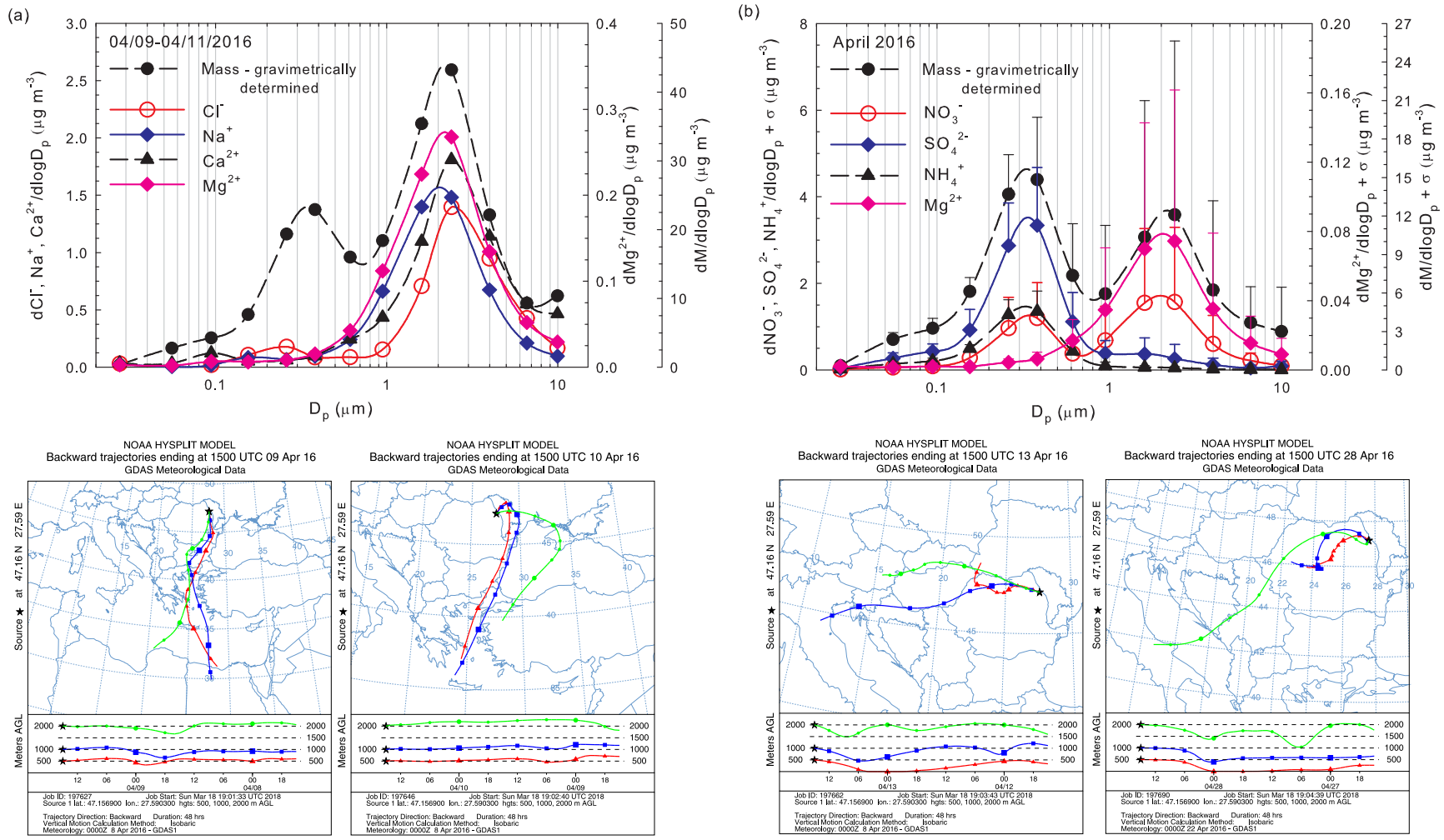

Figure 10. Evidence of long-range transport contributions from Saharan dust within the size distribution of particulate $\mathrm{Na}^{+}, \mathrm{Ca}^{2+}, \mathrm{Mg}^{2+}$, $\mathrm{Cl}^{-}$ions, and aerosol mass (a) and of air mass buoyancy phenomena within the size distribution of particulate $\mathrm{NH}_{4}^{+}, \mathrm{NO}_{3}^{-}, \mathrm{SO}_{4}^{2-}, \mathrm{Mg}^{2+}$ ions, and aerosol mass (b).

in the $0.946-1.6 \mu \mathrm{m}$ range). Such behaviour most likely reflects contributions from biomass burning over the entire year (Schmidl et al., 2008; Pachon et al., 2013). For both $\mathrm{Ca}^{2+}$ and $\mathrm{Mg}^{2+}$ ions, clear monomodal mass distributions with maxima in the 1.6 to $2.39 \mu \mathrm{m}$ size range were observed over the investigated period. Over the warm season, $\mathrm{Ca}^{2+}$ accounts for $(7.0 \pm 2.9) \%$ of the $\mathrm{PM}_{10}$ fraction and for $(5.5 \pm 2.9) \%$ of the $\mathrm{PM}_{2.5}$ fraction, while over the cold season it accounts for only $(3.0 \pm 0.6) \%$ of the $\mathrm{PM}_{10}$ and $(2.2 \pm 0.5) \%$ of the $\mathrm{PM}_{2.5}$ fraction. These observations indicate that the impact from soil dust resuspension could be more important during the warm (dry) season. Mineral dust may also explain the higher coarse fraction of $\mathrm{Mg}^{2+}$ (mineral source being $\mathrm{MgCO}_{3}$ ).

Clear evidence was obtained in this work that air mass origin highly influences the aerosol chemical composition at the investigated site. Annual averaged sector contributions, in terms of PM long-range transport, are shown in Fig. S2 while the seasonal contributions of PM and particulate inorganic and organic ions associated with different air mass origins are reported as radar charts in Fig. S3 (within Sect. S10). Figure S4 (within Sect. S10) highlights the percentage distributions for the identified and quantified ions and the gaseous concentrations of $\mathrm{NH}_{3}, \mathrm{HNO}_{3}$, and $\mathrm{HCl}$ for selected investigated events, predicted by ISORROPIA-II. Wonaschutz et al. (2015) suggested that in Vienna, Austria, air mass origin is the most important factor for bulk PM concentrations, chemical composition of the coarse fraction $(>1.5 \mu \mathrm{m})$, and mass size distribution, while it is less important for the chemical composition of the fine fraction $(<1.5 \mu \mathrm{m})$. Although Iasi is located far from the Mediterranean or Black Sea, over the warm season the sea salt chloride contribution to the aerosol budget in the area is not entirely excluded (Arsene et al., 2011). Moreover, dust particles originating from the Sahara are acknowledged as travelling across the tropical Atlantic Ocean (10-90 $\left.\mu \mathrm{g} \mathrm{m}^{-3}\right)$ and across the Mediterranean, affecting air quality in southern Europe $\left(10-60 \mu \mathrm{g} \mathrm{m}^{-3}\right.$ ) (Karydis et al., 2016). In the present work, particulate $\mathrm{Na}^{+}$and $\mathrm{Cl}^{-}$ions as tracers of sea salt aerosols (Tositti et al., 2014) were mainly observed in conditions predominated by contributions from air masses arriving in Iasi from the S-SE direction. However, one of the most interesting collected events was that of 9-11 April 2016. For this event, the $\mathrm{PM}_{10}$ fraction mass concentration was as high as $43.9 \mathrm{\mu g} \mathrm{m}^{-3}$, a value which is about 2 times higher than the average of the total events. These conditions were highly influenced by air masses originating from both the Saharan desert and the Mediterranean Sea. As shown in Fig. 10a, the size distributions of particulate $\mathrm{Na}^{+}, \mathrm{Ca}^{2+}, \mathrm{Mg}^{2+}, \mathrm{Cl}^{-}$ions, and their mass concentrations present a highly dominating mode with 
maxima at $2.39 \mu \mathrm{m}$. For this event, the $\left(\mathrm{Ca}^{2+}, \mathrm{Mg}^{2+}\right)$ and $\left(\mathrm{Na}^{+}, \mathrm{Cl}^{-}\right)$pairs showed statistically significant correlations (respectively, $r=0.94, p<0.001$ and $r=0.85, p<0.001$ ), suggesting common contributions from mineral Saharan dust $\left(\mathrm{Ca}^{2+}, \mathrm{Mg}^{2+}\right)$ and from sea salt marine aerosols $\left(\mathrm{Na}^{+}, \mathrm{Cl}^{-}\right)$. Moreover, Fig. 10a clearly shows that $\mathrm{Na}^{+}, \mathrm{Ca}^{2+}, \mathrm{Mg}^{2+}$, and $\mathrm{Cl}^{-}$make a very significant contribution to the total aerosol mass in the super-micron mode, with the maxima at $2.39 \mu \mathrm{m}$.

In April 2016, an interesting behaviour was also observed for the averaged mass size distributions of particulate $\mathrm{NH}_{4}^{+}$, $\mathrm{NO}_{3}^{-}, \mathrm{SO}_{4}^{2-}$, and $\mathrm{Mg}^{2+}$ (Fig. 10b). This month is highly affected by the atmospheric air mass buoyancy phenomenon, as shown by trajectory analysis for selected events and, while particulate $\mathrm{NH}_{4}^{+}$and $\mathrm{SO}_{4}^{2-}$ mainly resided in the fine mode with clear maxima at $381 \mathrm{~nm}, \mathrm{NO}_{3}^{-}$and $\mathrm{Mg}^{2+}$ also presented a predominant mode in the 1.6-2.39 $\mu \mathrm{m}$ fraction. Such distributions, corroborated with meteorological conditions, would actually suggest a possible heterogeneous formation route for $\mathrm{SO}_{4}^{2-}$ (Wang et al., 2012). In contrast, the adsorption of $\mathrm{HNO}_{3}$ on mineral dust and sea salt particles (Karydis et al., 2016) would become more important for $\mathrm{NO}_{3}^{-}$.

\section{Conclusions}

The atmospheric concentrations of particulate species including acetate, formate, fluoride, chloride, nitrite, nitrate, phosphate, sulfate, oxalate, sodium, potassium, ammonium, magnesium, and calcium were measured over 2016 at an urban site in Iasi, north-eastern Romania. The measurements were carried out using a cascade Dekati low-pressure impactor (DLPI), performing aerosol size classification in 13 specific fractions evenly distributed over the $0.0276-9.94 \mu \mathrm{m}$ size range.

The entire data set was analysed to investigate the seasonal variations in fine-particulate species and the meteorological effects and to examine the contributions of local and regional sources. ISORROPIA-II thermodynamic model runs were used to estimate the $\mathrm{pH}$ values of the collected atmospheric particles, as on the present database it was the best method to analyse particle acidity.

Within the aerosol mass concentration, the identified ions' mass brings contributions as high as $40.6 \%$ with the rest being unaccounted for yet. Fine-particulate $\mathrm{Cl}^{-}, \mathrm{NO}_{3}^{-}, \mathrm{NH}_{4}^{+}$, and $\mathrm{K}^{+}$exhibited clear seasonal variations with minima during the warm season, mainly due to cold season enhancement in the emission sources, changes in the mixing layer depth, and specific meteorological conditions (e.g. higher $\mathrm{RH}$ values prevailing in Iasi during the cold season). Fineparticulate $\mathrm{SO}_{4}^{2-}$ did not show much variation with respect to seasons. The measured concentrations of $\mathrm{NH}_{4}^{+}$and $\mathrm{NO}_{3}^{-}$in fine-mode $\left(\mathrm{PM}_{2.5}\right)$ aerosols were in reasonably good agreement with modelled values for the cold season but not for the warm season. This observation reflects the susceptibility of $\mathrm{NH}_{4} \mathrm{NO}_{3}$ aerosols to be lost due to volatility.
Clear evidences were obtained that $\mathrm{NH}_{4}^{+}$in $\mathrm{PM}_{2.5}$ was primarily associated with $\mathrm{SO}_{4}^{2-}$ and $\mathrm{NO}_{3}^{-}$. However, indirect ISORROPIA-II estimations showed that the atmosphere of Iasi might be ammonia rich during both cold and warm seasons, so that enough $\mathrm{NH}_{3}$ would be present to neutralize the $\mathrm{H}_{2} \mathrm{SO}_{4}, \mathrm{HNO}_{3}$, and $\mathrm{HCl}$ acidic components and to generate fine-particulate ammonium salts in the form of $\left(\mathrm{NH}_{4}\right)_{2} \mathrm{SO}_{4}, \mathrm{NH}_{4} \mathrm{NO}_{3}$, and $\mathrm{NH}_{4} \mathrm{Cl}$. Significant amounts of fine-particulate $\mathrm{NO}_{3}^{-}$were in fact detected during the cold season. The presence of possibly large amounts of $\mathrm{NH}_{3}$, the domination of $\left(\mathrm{NH}_{4}\right)_{2} \mathrm{SO}_{4}$ over $\mathrm{NH}_{4} \mathrm{NO}_{3}$ and $\mathrm{NH}_{4} \mathrm{Cl}$, and the high $\mathrm{RH}$ conditions in the cold season (likely leading to dissolution of a significant fraction of atmospheric $\mathrm{HNO}_{3}$ and $\mathrm{NH}_{3}$ ) are among the most important driving forces enhancing the fine-particulate $\mathrm{NO}_{3}^{-}$and $\mathrm{NH}_{4}^{+}$distribution at the investigated site.

Most probably, gaseous $\mathrm{NH}_{3}$ is not only a precursor of $\mathrm{NH}_{4}^{+}$formation, but it also affects the occurrence of $\mathrm{NO}_{3}^{-}$ and eventually $\mathrm{Cl}^{-}$in $\mathrm{PM}_{2.5}$ via neutralization processes. The chemical composition database concerning $\mathrm{PM}_{2.5}$ (and $\mathrm{PM}_{10}$ ), combined with predictions from ISORROPIA-II run in the forward mode, allow us to suggest that $\mathrm{NH}_{3}$ was most probably present at a sufficiently high concentration to promote fine-particle acidity neutralization during both the cold and the warm seasons. Although it is known that running ISORROPIA-II in the forward mode with only aerosol concentrations as input may result in a bias in the predicted $\mathrm{pH}$ due to the repartitioning of ammonia in the model, this approach was the only one that allowed for a reasonable interpretation of the obtained results.

Over the warm season, $\sim 35 \%$ of the total analysed samples presented $\mathrm{pH}$ values in the very strong acidity fraction (0-3 $\mathrm{pH}$ units range), while over the cold season the fraction of samples in this $\mathrm{pH}$ range was $\sim 43 \%$. However, while during the warm season $\sim 24-25 \%$ of the acidic samples were in the $1-2 \mathrm{pH}$ range (reflecting mainly contributions from very strong inorganic acids), over the cold season an $\sim 40 \%$ fraction in the $1-3 \mathrm{pH}$ range would reflect possible contributions from other acidic type species (i.e. organics). The observed changes in aerosol acidity could potentially impact the gasparticle partitioning of semi-volatile organic acids.

Data availability. Data are available upon request to the contact author Cecilia Arsene (carsene@uaic.ro).

Supplement. The supplement related to this article is available online at: https://doi.org/10.5194/acp-18-5879-2018-supplement.

Competing interests. The authors declare that they have no conflict of interest. 
Acknowledgements. The authors acknowledge the financial support provided by UEFISCDI within the PN-III-P4-ID-PCE-2016-0299 (AI-FORECAST), PN-II-PCE-2011-3-0471 (EVOLUTION-AIR), and PN-II-RU-TE-2014-4-2461 (SOS-AROMATIC) projects. The European Union's Horizon 2020 research and innovation programme, through the EUROCHAMP-2020 Infrastructure Activity Grant (grant agreement no. 730997) and Chemical On-Line cOmpoSition and Source Apportionment of fine aerosoLs COLOSSAL grant (CA16109), is gratefully acknowledged. The authors also acknowledge the NOAA Air Resources Laboratory (ARL) for the provision of the HYSPLIT transport and dispersion model and/or READY website (http://www.ready.noaa.gov) used in this publication.

Edited by: Leiming Zhang

Reviewed by: two anonymous referees

\section{References}

Adams, P. J., Seinfeld, J. H., and Koch, D. M.: Global concentration of tropospheric sulfate, nitrate and ammonium aerosol simulated in a general circulation model, J. Geophys. Res., 104, 1379113823, https://doi.org/10.1029/1999JD900083, 1999.

Akagi, S. K., Yokelson, R. J., Wiedinmyer, C., Alvarado, M. J., Reid, J. S., Karl, T., Crounse, J. D., and Wennberg, P. O.: Emission factors for open and domestic biomass burning for use in atmospheric models, Atmos. Chem. Phys., 11, 4039-4072, https://doi.org/10.5194/acp-11-4039-2011, 2011.

Aksoyoglu, S., Ciarelli, G., El-Haddad, I., Baltensperger, U., and Prévôt, A. S. H.: Secondary inorganic aerosols in Europe: sources and the significant influence of biogenic VOC emissions, especially on ammonium nitrate, Atmos. Chem. Phys., 17, 77577773, https://doi.org/10.5194/acp-17-7757-2017, 2017.

Alastuey, A., Querol, X., Rodríguez, S., Plana, F., LopezSoler, A., Ruiz, C., and Mantilla, E.: Monitoring of atmospheric particulate matter around sources of inorganic secondary inorganic aerosol, Atmos. Environ., 38, 4979-4992, https://doi.org/10.1016/j.atmosenv.2004.06.026, 2004.

Alastuey, A., Querol, X., Aas, W., Lucarelli, F., Pérez, N., Moreno, T., Cavalli, F., Areskoug, H., Balan, V., Catrambone, M., Ceburnis, D., Cerro, J. C., Conil, S., Gevorgyan, L., Hueglin, C., Imre, K., Jaffrezo, J.-L., Leeson, S. R., Mihalopoulos, N., Mitosinkova, M., O’Dowd, C. D., Pey, J., Putaud, J.-P., Riffault, V., Ripoll, A., Sciare, J., Sellegri, K., Spindler, G., and Yttri, K. E.: Geochemistry of $\mathrm{PM}_{10}$ over Europe during the EMEP intensive measurement periods in summer 2012 and winter 2013, Atmos. Chem. Phys., 16, 6107-6129, https://doi.org/10.5194/acp16-6107-2016, 2016.

Aneja, V. P., Chauhan, J. P., and Walker, J. T.: Characterization of atmospheric ammonia emissions from swine waste storage and treatment lagoons, J. Geophys. Res., 105, 11535-11545, https://doi.org/10.1029/2000JD900066, 2000.

Arsene, C., Olariu, R. I., and Mihalopoulos, N.: Chemical composition of rainwater in the north-eastern Romania, Iasi region (2003-2006), Atmos. Environ., 41, 9452-9467, https://doi.org/10.1016/j.atmosenv.2007.08.046, 2007.

Arsene, C., Olariu, R. I., Zarmpas, P., Kanakidou, M., and Mihalopoulos, N.: Ion composition of coarse and fine parti- cles in Iasi, north-eastern Romania. Implications for aerosols chemistry in the area, Atmos. Environ., 45, 906-916, https://doi.org/10.1029/2000JD900066, 2011.

Athanasopoulou, E., Tombrou, M., Pandis, S. N., and Russell, A. G.: The role of sea-salt emissions and heterogeneous chemistry in the air quality of polluted coastal areas, Atmos. Chem. Phys. 8, 5755-5769, https://doi.org/10.5194/acp-8-5755-2008, 2008.

Bacarella, A. L., Grunwald, E., Marshall, H. P., and Purlee, E. L.: The potentiometric measurement of acid dissociation constants and $\mathrm{pH}$ in the system methanol-water. $\mathrm{pK}_{\mathrm{a}}$ values for carboxylic acids and anilinium ions, J. Org. Chem., 20, 747-762, https://doi.org/10.1021/jo01124a007, 1955.

Backes, A. M., Aulinger, A., Bieser, J., Matthias, V., and Quante, M.: Ammonia emissions in Europe, part II: How ammonia emission abatement strategies affect secondary aerosols, Atmos. Environ., 126, 153-161, https://doi.org/10.1016/j.atmosenv.2015.11.039, 2016.

Bardouki, H., Liakakou, H., Economou, C., Sciare, J., Smolik, J., Zdimal, V., Eleftheriadis, K., Lazaridis, M., Dye, C., and Mihalopoulos, N.: Chemical composition of sizeresolved atmospheric aerosols in the eastern Mediterranean during summer and winter, Atmos. Environ., 37, 195-208, https://doi.org/10.1016/S1352-2310(02)00859-2, 2003.

Behera, S. N. and Sharma, M.: Transformation of atmospheric ammonia and acid gases into components of $\mathrm{PM}_{2.5}$ : an environmental chamber study, Environ. Sci. Pollut. R., 19, 1187-1197, https://doi.org/10.4209/aaqr.2012.11.0328, 2012.

Behera, S. N., Betha, R., and Balasubramanian, R.: Insights into chemical coupling among acidic gases, ammonia and secondary inorganic aerosols, Aerosol Air Qual. Res., 13, 1282-1296, https://doi.org/10.1007/s11356-011-0635-9, 2013.

Bressi, M., Sciare, J., Ghersi, V., Bonnaire, N., Nicolas, J. B., Petit, J.-E., Moukhtar, S., Rosso, A., Mihalopoulos, N., and Féron, A.: A one-year comprehensive chemical characterisation of fine aerosol $\left(\mathrm{PM}_{2.5}\right)$ at urban, suburban and rural background sites in the region of Paris (France), Atmos. Chem. Phys., 13, 78257844, https://doi.org/10.5194/acp-13-7825-2013, 2013.

Brook, R. D.: Cardiovascular effects of air pollution, Clin. Sci., 115, 175-187, https://doi.org/10.1042/CS20070444, 2008.

Christian, T. J., Yokelson, R. J., Cárdenas, B., Molina, L. T., Engling, G., and Hsu, S.-C.: Trace gas and particle emissions from domestic and industrial biofuel use and garbage burning in central Mexico, Atmos. Chem. Phys., 10, 565-584, https://doi.org/10.5194/acp-10-565-2010, 2010.

Clegg, S. L., Brimblecombe, P., and Wexler, A. S.: Thermodynamic model of the system $\mathrm{H}^{+}-\mathrm{NH}_{4}^{+}-\mathrm{SO}_{4}^{2-}-\mathrm{NO}_{3}^{-}-\mathrm{H}_{2} \mathrm{O}$ at tropospheric temperatures, J. Phys. Chem. A, 102, 2137-2154, https://doi.org/10.1021/jp973042r, 1998.

Cziczo, D. J., Nowak, J. B., Hu, J. H., and Abbatt, J. P. D.: Infrared spectroscopy of model tropospheric aerosols as a function of relative humidity: observation of deliquescence and crystallization, J. Geophys. Res., 102, 18843-18850, https://doi.org/10.1029/97JD01361, 1997.

Directive 2008/50/EC: European Parliament and of the Council of 21 May 2008 on ambient air quality and cleaner air for Europe, Official Journal L 152, 11/06/2008, 0001-0044, 2008.

Dockery, D. W., Cunningham, J., Damokosh, A. I., Neas, L. M., Spengler, J. D., Koutrakis, P., Ware, J. H., Raizenne, M., and Speizer, F. E.: Health effects of acid aerosols on North Ameri- 
can children: respiratory symptoms, Environ. Health Persp., 104, 500-505, 1996.

Dominici, F., Peng, D. K., Bell, M. L., Pham, L., McDermott, A., Zeger, S. L., and Samet, J. M.: Fine particulate air pollution and hospital admission for cardiovascular and respiratory diseases, JAMA, 295, 1127-1134, https://doi.org/10.1001/jama.295.10.1127, 2006.

Dougle P. G., Veefkind J. P., and ten Brink, H. M.: Cristallisation of mixtures of ammonium nitrate, ammonium sulfate and soot, J. Aerosol Sci., 29, 375-386, https://doi.org/10.1016/S00218502(97)10003-9, 1998.

European Environment Agency (EEA) Report: Air quality in Europe-2015 report, ISSN 1977-8449, Report No. 5, 2015.

Fang, T., Guo, H., Zeng, L., Verma, V., Nenes, A., and Weber, R. J.: Highly acidic ambient particles, soluble metals, and oxidative potential: A link between sulfate and aerosol toxicity, Environ. Sci. Technol., 51, 2611-2620, https://doi.org/10.1021/acs.est.6b06151, 2017.

Fountoukis, C. and Nenes, A.: ISORROPIA II: a computationally efficient thermodynamic equilibrium model for $\mathrm{K}^{+}-\mathrm{Ca}^{2+}$ $\mathrm{Mg}^{2+}-\mathrm{NH}_{4}^{+}-\mathrm{Na}^{+}-\mathrm{SO}_{4}^{2-}-\mathrm{NO}_{3}^{-}-\mathrm{Cl}^{-}$, and $\mathrm{H}_{2} \mathrm{O}$ aerosols, Atmos. Chem. Phys., 7, 4639-4659, https://doi.org/10.5194/acp-74639-2007, 2007.

Fountoukis, C., Nenes, A., Sullivan, A., Weber, R., Van Reken, T., Fischer, M., Matías, E., Moya, M., Farmer, D., and Cohen, R. C.: Thermodynamic characterization of Mexico City aerosol during MILAGRO 2006, Atmos. Chem. Phys., 9, 2141-2156, https://doi.org/10.5194/acp-9-2141-2009, 2009.

Freney, E. J., Sellegri, K., Canonaco, F., Colomb, A., Borbon, A., Michoud, V., Doussin, J.-F., Crumeyrolle, S., Amarouche, N., Pichon, J.-M., Bourianne, T., Gomes, L., Prevot, A. S. H., Beekmann, M., and Schwarzenböeck, A.: Characterizing the impact of urban emissions on regional aerosol particles: airborne measurements during the MEGAPOLI experiment, Atmos. Chem. Phys., 14, 1397-1412, https://doi.org/10.5194/acp14-1397-2014, 2014

Gerasopoulos, E., Koulouri, E., Kalivitis, N., Kouvarakis, G., Saarikoski, S., Mäkelä, T., Hillamo, R., and Mihalopoulos, N.: Size-segregated mass distributions of aerosols over Eastern Mediterranean: seasonal variability and comparison with AERONET columnar size-distributions, Atmos. Chem. Phys., 7, 2551-2561, https://doi.org/10.5194/acp-7-2551-2007, 2007.

Guo, H., Xu, L., Bougiatioti, A., Cerully, K. M., Capps, S. L., Hite Jr., J. R., Carlton, A. G., Lee, S.-H., Bergin, M. H., Ng, N. L., Nenes, A., and Weber, R. J.: Fine-particle water and $\mathrm{pH}$ in the southeastern United States, Atmos. Chem. Phys., 15, 5211-5228, https://doi.org/10.5194/acp-15-5211-2015, 2015.

Guo, H., Sullivan, A. P., Campuzano-Jost, P., Schroder, J. C., LopezHilfiker, F. D., Dibb, J. E., Jimenez, J. L., Thornton, J. A., Brown, S. S., Nenes, A., and Weber, R. J.: Fine particle pH and the partitioning of nitric acid during winter in the northeastern United States, J. Geophys. Res.-Atmos., 121, 10355-10376, https://doi.org/10.1002/2016JD025311, 2016.

Gwynn, R. C., Burnett, R. T., and Thurston, G. D.: A time-series analysis of acidic particulate matter and daily mortality and morbidity in the Buffalo, New York, region, Environ. Health Persp., 108, 125-133, 2000.

Harrison, R. M. and Kitto, A. M. N.: Estimation of the rate constant for the reaction of acid sulfate aerosol with $\mathrm{NH}_{3}$ gas from atmospheric measurements, J. Atmos. Chem., 15, 133-143, https://doi.org/10.1007/BF00053755, 1992.

Hasheminassab, S., Daher, N., Saffari, A., Wang, D., Ostro, B. D., and Sioutas, C.: Spatial and temporal variability of sources of ambient fine particulate matter $\left(\mathrm{PM}_{2.5}\right)$ in California, Atmos. Chem. Phys., 14, 12085-12097, https://doi.org/10.5194/acp-1412085-2014, 2014.

Hennigan, C. J., Izumi, J., Sullivan, A. P., Weber, R. J., and Nenes, A.: A critical evaluation of proxy methods used to estimate the acidity of atmospheric particles, Atmos. Chem. Phys., 15, 27752790, https://doi.org/10.5194/acp-15-2775-2015, 2015.

Hitzenberger, R., Ctyroky, P., Berner, A., Tursic, J., Podkrajsek, B., and Grgic, I.: Size distribution of black (BC) and total carbon (TC) in Vienna and Ljubljana, Chemosphere, 65, 2106-2113, https://doi.org/10.1016/j.chemosphere.2006.06.042, 2006.

Holton, J. R.: An Introduction to Dynamic Meteorology, 4th Edn., Academic Press, New York, 1979.

Huang, X.-F., He, L.-Y., Hu, M., Canagaratna, M. R., Sun, Y., Zhang, Q., Zhu, T., Xue, L., Zeng, L.-W., Liu, X.-G., Zhang, Y.-H., Jayne, J. T., Ng, N. L., and Worsnop, D. R.: Highly time-resolved chemical characterization of atmospheric submicron particles during 2008 Beijing Olympic Games using an Aerodyne High-Resolution Aerosol Mass Spectrometer, Atmos. Chem. Phys., 10, 8933-8945, https://doi.org/10.5194/acp-108933-2010, 2010.

Ianniello, A., Spataro, F., Esposito, G., Allegrini, I., Rantica, E., Ancora, M. P., Hu, M., and Zhu, T.: Occurrence of gas phase ammonia in the area of Beijing (China), Atmos. Chem. Phys., 10, 9487-9503, https://doi.org/10.5194/acp-10-9487-2010, 2010.

Ianniello, A., Spataro, F., Esposito, G., Allegrini, I., Hu, M., and Zhu, T.: Chemical characteristics of inorganic ammonium salts in $\mathrm{PM}_{2.5}$ in the atmosphere of Beijing (China), Atmos. Chem. Phys., 11, 10803-10822, https://doi.org/10.5194/acp-11-108032011, 2011.

Ichim, L., Vlaicu, M., Draxineanu, A., and Alexandru, C.: Populatia Romaniei pe localitati la 1 Ianuarie 2016, in INS 2016, edited by: Iagar, E. M., Pisica, S., and Baltateanu, L., ISSN: 2066-2181, Institutul National de Statistica, Romania, 130 pp., 2016.

IPCC, 2013: Summary for Policymakers, in: Climate Change 2013: The Physical Science Basis. Contribution of Working Group I to the Fifth Assessment Report of the Intergovernmental Panel on Climate Change, edited by: Stocker, T. F., Qin, D., Plattner, G. K., Tignor, M., Allen, S. K., Boschung, J., Nauels, A., Xia, Y., Bex, V., and Midgley, P. M., Cambridge University Press, Cambridge, United Kingdom and New York, NY, USA, 1-30, https://doi.org/10.1017/CBO9781107415324.004, 2013.

ISORROPIA: http://isorropia.eas.gatech.edu/, last access: 11 July 2017.

James, P. M.: An objective classification method for Hess and Brezowsky Grosswetterlagen over Europe, Theor. Appl. Climatol., 88, 17-42, https://doi.org/10.1007/s00704-006-0239-3, 2007.

Jang, M., Czoschke, N. M., Lee, S., and Kamens, R. M.: Heterogeneous atmospheric aerosol production by acidcatalyzed particle-phase reactions, Science, 298, 814-817, https://doi.org/10.1126/science.1075798, 2002.

Kadowaki, S.: On the nature of the atmospheric oxidation processes of $\mathrm{SO}_{2}$ to sulfate and of $\mathrm{NO}_{2}$ to nitrate on the basis of diurnal variations of sulfate, nitrate, and other pollu- 
tants in an urban area, Environ. Sci. Technol., 20, 1249-1253, https://doi.org/10.1021/es00154a009, 1986.

Kai, Z., Yuesi, W., Tianxue, W., Yousef, M., and Frank, M.: Properties of nitrate, sulfate and ammonium in typical polluted atmospheric aerosols $\left(\mathrm{PM}_{10}\right)$ in Beijing, Atmos. Res., 84, 67-77, https://doi.org/10.1016/j.atmosres.2006.05.004, 2007.

Karydis, V. A., Tsimpidi, A. P., Lei, W., Molina, L. T., and Pandis, S. N.: Formation of semivolatile inorganic aerosols in the Mexico City Metropolitan Area during the MILAGRO campaign, Atmos. Chem. Phys., 11, 13305-13323, https://doi.org/10.5194/acp-1113305-2011, 2011.

Karydis, V. A., Tsimpidi, A. P., Pozzer, A., Astitha, M., and Lelieveld, J.: Effects of mineral dust on global atmospheric nitrate concentrations, Atmos. Chem. Phys., 16, 1491-1509, https://doi.org/10.5194/acp-16-1491-2016, 2016.

Keene, W. C., Pszenny, A. A. P., Maben, J. R., Stevenson, E., and Wall, A.: Closure evaluation of size-resolved aerosol $\mathrm{pH}$ in the New England coastal atmosphere during summer, J. Geophys. Res., 109, D23307, https://doi.org/10.1029/2004JD004801, 2004.

Kocak, M., Mihalopoulos, N., and Kubilay, N.: Contributions of natural sources to high $\mathrm{PM}_{10}$ and $\mathrm{PM}_{2.5}$ events in the eastern Mediterranean, Atmos. Environ., 41, 3806-3818, https://doi.org/10.1016/j.atmosenv.2007.01.009, 2007.

Laongsri, B. and Harrison, R. M.: Atmospheric behaviour of particulate oxalate at UK urban background and rural sites, Atmos. Environ., 71, 319-326, https://doi.org/10.1016/j.atmosenv.2013.02.015, 2013.

Lelieveld, J., Evans, J. S., Fnais, M., Giannadaki, D., and Pozzer, A.: The contribution of outdoor air pollution sources to premature mortality on a global scale, Nature, 525, 367-371, https://doi.org/10.1038/nature15371, 2015.

Li, T. C., Yuan, C. S., Lo, K. C., Hung, C. H., Wu, S. P., and Tong, C.: Seasonal variation and chemical characteristics of atmospheric particles at Three Islands in the Taiwan Street, Aerosol Air Qual. Res., 15, 2277-2290, https://doi.org/10.4209/aaqr.2015.03.0153, 2015.

Li, W., Shi, Z., Zhang, D., Zhang, X., Li, P., Feng, Q., Yuan, Q., and Wang, W.: Haze particles over a coal-burning region in the China Loess Plateau in winter: three flight missions in December 2010, J. Geophys. Res., 117, D12306, https://doi.org/10.1029/2012JD017720, 2012.

Markovic, M. Z., Hayden, K. L., Murphy, J. G., Makar, P. A., Ellis, R. A., Chang, R. Y.-W., Slowik, J. G., Mihele, C., and Brook, J.: The effect of meteorological and chemical factors on the agreement between observations and predictions of fine aerosol composition in southwestern Ontario during BAQS-Met, Atmos. Chem. Phys., 11, 3195-3210, https://doi.org/10.5194/acp11-3195-2011, 2011.

Masiol, M., Squizzato, S., Ceccato, D., Rampazzo, G., and Pavoni, B.: Determining the influence of different atmospheric circulation patterns on $\mathrm{PM}_{10}$ chemical composition in a source apportionment study, Atmos. Environ., 63, 117-124, https://doi.org/10.1016/j.atmosenv.2012.09.025, 2012.

Matsumoto, K. and Tanaka, H.: Formation and dissociation of atmospheric particulate nitrate and chloride: an approach based on phase equilibrium, Atmos. Environ., 30, 639-648, https://doi.org/10.1016/1352-2310(95)00290-1, 1996.
Meng, Z. Y., Seinfeld, J. H., Saxena, P., and Kim, Y. P.: Atmospheric gas - aerosol equilibrium IV. Thermodynamics of carbonates, Aerosol Sci. Tech., 23, 131-154, https://doi.org/10.1080/02786829508965300, 1995.

Meng, Z. Y., Lin, W. L., Jiang, X. M., Yan, P., Wang, Y., Zhang, Y. M., Jia, X. F., and Yu, X. L.: Characteristics of atmospheric ammonia over Beijing, China, Atmos. Chem. Phys., 11, 61396151, https://doi.org/10.5194/acp-11-6139-2011, 2011.

Meskhidze, N., Chameides, W. L., Nenes, A., and Chen, G.: Iron mobilization in mineral dust: Can anthropogenic $\mathrm{SO}_{2}$ emissions affect ocean productivity?, Geophys. Res. Lett., 30, 2085, https://doi.org/10.1029/2003GL018035, 2003.

Metzger, S., Mihalopoulos, N., and Lelieveld, J.: Importance of mineral cations and organics in gas-aerosol partitioning of reactive nitrogen compounds: case study based on MINOS results, Atmos. Chem. Phys., 6, 2549-2567, https://doi.org/10.5194/acp6-2549-2006, 2006.

Nenes, A., Pilinis, C., and Pandis, S. N.: Continued development and testing of a new thermodynamic aerosol module for urban and regional air quality models, Atmos. Environ., 33, 15531560, https://doi.org/10.1016/S1352-2310(98)00352-5, 1999.

Nowak, J. B., Huey, L. G., Russell, A. G., Tian, D., Neuman, J. A., Orsini, D., Sjostedt, S. J., Sullivan, A. P., Tanner, D. J., Weber, R. J., Nenes, A., Edgerton, E., and Fehsenfeld, F. C.: Analysis of urban gas phase ammonia measurements from the 2002 Atlanta Aerosol Nucleation and Real-Time Characterization Experiment (ANARChE), J. Geophys. Res., 111, D17308, https://doi.org/10.1029/2006JD007113, 2006.

Olariu, R. I., Vione, D., Grinberg, N., and Arsene C.: Applications of liquid chromatographic techniques in the chemical characterization of atmospheric aerosols, J. Liq. Chromatogr. R. T., 38, 322-348, https://doi.org/10.1080/10826076.2014.941256, 2015.

Ostro, B., Malig, B., Broadwin, R., Basu, R., Gold, E. B., Bromberger, J. T., Derby, C., Feinstein, S., Greendale, G. A., Jackson, E. A., Kravitz, H. M., Matthews, K. A., Sternfeld, B., Tomey, K., Green, R. R., and Green, R.: Chronic $\mathrm{PM}_{2.5}$ exposure and inflammation: determining sensitive subgroups in mid-life women, Environ. Res., 132, 168-175, https://doi.org/10.1016/j.envres.2014.03.042, 2014.

Pachon, J. E., Weber, R. J., Zhang, X., Mulholland, J. A., and Russell, A. G.: Revising the use of potassium (K) in the source apportionment of $\mathrm{PM}_{2.5}$, Atmos. Pollut. Res., 4, 14-21, https://doi.org/10.5094/APR.2013.002, 2013.

Pandolfi, M., Amato, F., Reche, C., Alastuey, A., Otjes, R. P., Blom, M. J., and Querol, X.: Summer ammonia measurements in a densely populated Mediterranean city, Atmos. Chem. Phys., 12, 7557-7575, https://doi.org/10.5194/acp-12-7557-2012, 2012.

Park, R. J., Jacob, D. J., Field, B. D., Yantosca, R. M., and Chin, M.: Natural and transboundary pollution influences on sulfate-nitrate-ammonium aerosols in the United States: implications for policy, J. Geophys. Res., 109, D15204, https://doi.org/10.1029/2003JD004473, 2004.

Pathak, R. K., Wu, W. S., and Wang, T.: Summertime $\mathrm{PM}_{2.5}$ ionic species in four major cities of China: nitrate formation in an ammonia-deficient atmosphere, Atmos. Chem. Phys., 9, 17111722, https://doi.org/10.5194/acp-9-1711-2009, 2009.

Pathak, R. K., Wang, T., and Wu, W. S.: Nighttime enhancement of $\mathrm{PM}_{2.5}$ nitrate in ammonia-poor atmospheric conditions in Beijing and Shanghai: Plausible contributions of heterogeneous 
hydrolysis of $\mathrm{N}_{2} \mathrm{O}_{5}$ and $\mathrm{HNO}_{3}$ partitioning, Atmos. Environ., 45, 1183-1191, https://doi.org/10.1016/j.atmosenv.2010.09.003, 2011.

Pope, C. A., Burnett, R. T., Thurston, G. D., Thun, M. J., Calle, E. E., Krewski, D., and Godleski, J. J.: Cardiovascular mortality and long-term exposure to particulate air pollution: epidemiological evidence of general pathophysiological pathways of disease, Circulation, 109, 71-77, https://doi.org/10.1161/01.CIR.0000108927.80044.7F, 2004.

Prinn, R. G.: The cleansing capacity of atmosphere, Annu. Rev. Env. Resour., 28, https://doi.org/10.1146/annurev.energy.28.011503.163425, 2003.

Querol, X., Alastuey, A., Ruiz, C. R., Artinano, B., Hansson, H. C., Harrison, R. M., Buringh, E., ten Brink, H. M., Lutz, M., Bruckmann, P., Straehl, P., and Schneider, J.: Speciation and origin of $\mathrm{PM}_{10}$ and $\mathrm{PM}_{2.5}$ in selected European cities, Atmos. Environ., 38, 6547-6555, https://doi.org/10.1016/j.atmosenv.2004.08.037, 2004.

Ramanathan, V., Crutzen, P. J., Kiehl, J. T., and Rosenfeld, D., Aerosols, climate, and the hydrological cycle, Science, 294, 2119-2124, https://doi.org/10.1126/science.1064034, 2001.

Ravishankara, A. R.: Heterogeneous and multiphase chemistry in the troposphere, Science, 276, 1058-1065, https://doi.org/10.1126/science.276.5315.1058, 1997.

Rolph, G., Stein, A., and Stunder, B.: Real-time Environmental Applications and Display sYstem: READY, Environ. Modell. Softw., 95, 210-228, https://doi.org/10.1016/j.envsoft.2017.06.025, 2017.

Sandrini, S., van Pinxteren, D., Giulianelli, L., Herrmann, H., Poulain, L., Facchini, M. C., Gilardoni, S., Rinaldi, M., Paglione, M., Turpin, B. J., Pollini, F., Bucci, S., Zanca, N., and Decesari, S.: Size-resolved aerosol composition at an urban and a rural site in the Po Valley in summertime: implications for secondary aerosol formation, Atmos. Chem. Phys., 16, 1087910897, https://doi.org/10.5194/acp-16-10879-2016, 2016.

Schmidl, C., Marr, I. L., Caseiro, A., Kotianova, P., Berner, A., Bauer, H., Kasper-Giebla A., and Puxbaum, H.: Chemical characterisation of fine particle emissions from wood stove combustion of common woods growing in midEuropean Alpine regions, Atmos. Environ., 42, 126-141, https://doi.org/10.1016/j.atmosenv.2007.09.028, 2008.

Schwarz, J., Chi, X., Maenhaut, W., Civis, M., Hovorka, J., and Smolik, J.: Elemental and organic carbon in atmospheric aerosols at downtown and suburban sites in Prague, Atmos. Res., 90, 287302, https://doi.org/10.1016/j.atmosres.2008.05.006, 2008.

Schwarz, J., Stefancova, L., Maenhaut, W., Smolik, J., and Zdimal, V.: Mass and chemically speciated size distribution of Prague aerosol using an aerosol dryer - The influence of air mass origin, Sci Total. Environ., 437, 348-362, https://doi.org/10.1016/j.scitotenv.2012.07.050, 2012.

Seinfeld, J. H. and Pandis, S. N.: Atmospheric Chemistry and Physics: From Air Pollution to Climate Change, Wiley, New York, 1998.

Sharma, M., Kishore, S., Tripathi, S. N., and Behera, S. N.: Role of atmospheric ammonia in the secondary particulate matter: a study at Kanpur, India, J. Atmos. Chem., 58, 1-17, https://doi.org/10.1007/s10874-007-9074-x, 2007.
Shon, Z., Ghosh, S., Kim, K., Song, S., Jung, K., and Kim, N.: Analysis of water-soluble ions and their precursor gases over diurnal cycle, Atmos. Res., 132-133, 309-321, https://doi.org/10.1016/j.atmosres.2013.06.003, 2013.

Sicard, P., Lesne, O., Alexandre, N., Mangin, A., and Collomp, R.: Air quality trends and potential health effects e development of an aggregate risk index, Atmos. Environ., 45, 1145-1153, https://doi.org/10.1016/j.atmosenv.2010.12.052, 2011.

Stein, A. F., Draxler, R. R., Rolph, G. D., Stunder, B. J. B., Cohen, M. D., and Ngan, F.: NOAA's HYSPLIT atmospheric transport and dispersion modeling system, B. Am. Meteorol. Soc., 96, 2059-2077, https://doi.org/10.1175/BAMS-D-14$00110.1,2015$.

Stelson, A. W. and Seinfeld, J. H.: Relative humidity and $\mathrm{pH}$ dependence of the vapour pressure of ammonium nitratenitric acid solutions at $25^{\circ} \mathrm{C}$, Atmos. Environ., 16, 993-1000, https://doi.org/10.1016/0004-6981(82)90185-8, 1982.

Stockwell, W. R. and Calvert, J. G.: The mechanism of the $\mathrm{HO}-\mathrm{SO}_{2}$ reaction, Atmos. Environ., 17, 2231-2235, https://doi.org/10.1016/0004-6981(83)90220-2, 1983.

Stockwell, W. R., Watson, J. G., Robinson, N. F., Steiner, W., and Sylte, W.: The ammonium nitrate particle equivalent of $\mathrm{NO}_{x}$ emissions for wintertime conditions in Central California's San Joaquin Valley, Atmos. Environ., 34, 4711-4717, https://doi.org/10.1016/S1352-2310(00)00148-5, 2000.

Sun, J., Zhang, Q., Canagaratna, M. R., Zhang, Y., Ng, N. L., Sun, Y., Jayne, J. T., Zhang, X., Zhang, X., and Worsnop, D. R.: Highly time- and size-resolved characterization of submicron aerosol particles in Beijing using an Aerodyne Aerosol Mass Spectrometer, Atmos. Environ., 44, 131-140, https://doi.org/10.1016/j.atmosenv.2009.03.020, 2010.

Sutton, M. A., Howard, C. M., Erisman, J. W., Billen, G., Bleeker, A., Grennfelt, P., van Grinsven, H., and Grizzetti, B.: The European Nitrogen Assessment: Sources, Effects and Policy Perspectives, Cambridge University Press, 2011.

Tolis, E. I., Saraga, D. E., Lytra, M. K., Papathanasiou, A. C., Bougaidis, P. N., Prekas-Patronakis, O. E., Ioannidis, I. I., and Bartzis, J. G.: Concentration and chemical composition of $\mathrm{PM}_{2.5}$ for a one-year period at Thessaloniki, Greece: a comparison between city and port area, Atmos. Environ., 113, 197-207, https://doi.org/10.1016/j.atmosenv.2015.05.014, 2015.

Tositti, L., Brattich, E., Masiol, M., Baldacci, D., Ceccato, D., Parmeggiani, S., Stracquadanio, M., and Zappoli, S.: Source apportionment of particulate matter in a large city of southeastern Po Valley (Bologna, Italy), Environ. Sci. Pollut. R., 21, 872-890, https://doi.org/10.1007/s11356-013-1911-7, 2014.

Trebs, I., Metzger, S., Meixner, F. X., Helas, G., Hoffer, A., Andreae, M. O., Moura, M. A. L., da Silva Jr., R. S., Rudich, Y., Falkovich, A. H., Artaxo, P., and Slanina, J.: The $\mathrm{NH}_{4}^{+}-\mathrm{NO}_{3}^{-}-$ $\mathrm{Cl}^{-}-\mathrm{SO}_{4}^{2-}-\mathrm{H}_{2} \mathrm{O}$ aerosol system and its gas phase precursors at a pasture site in the Amazon Basin: How relevant are mineral cations and soluble organic acids?, J. Geophys. Res., 110, D07303, https://doi.org/10.1029/2004JD005478, 2005.

Tsai, Y. I. and Cheng, M. T.: Visibility and aerosol chemical compositions near the coastal area in Central Taiwan, Sci. Total Environ., 231, 37-51, https://doi.org/10.1016/S0048-9697(99)000935,1999 .

Tursic, J., Podkrajsek, B., Grgic, I., Ctyroky, P., Berner, A., Dusek, U., and Hitzenberger, R.: Chemical composition and hygro- 
scopic properties of size-segregated aerosol particles collected at the Adriatic coast of Slovenia, Chemosphere, 63, 1193-1202, https://doi.org/10.1016/j.chemosphere.2005.08.040, 2006.

Utsunomiya, A. and Wakamatsu, S.: Temperature and humidity dependence on aerosol composition in the northern Kyushu, Japan, Atmos. Environ., 30, 2379-2386, https://doi.org/10.1016/13522310(95)00350-9, 1996.

Vione, D., Maurino, V., Minero, C., and Pelizzetti, E.: The atmospheric chemistry of hydrogen peroxide: A Review, Ann. Chim. (Rome), 93, 477-488, 2003.

Voutsa, D., Samara, C., Manoli, E., Lazarou, D., and Tzoumaka, P.: Ionic composition of $\mathrm{PM}_{2.5}$ at urban sites of northern Greece: secondary inorganic aerosol formation, Environ. Sci. Pollut. R., 21, 4995-5006, https://doi.org/10.1007/s11356-013-2445-8, 2014.

Wang, H. L., Qiao, L. P., Lou, S. R., Zhou, M., Ding, A. J., Huang, H. Y., Chen, J. M., Wang, Q., Tao, S. K., Chen, C. H., Li, L., and Huang, C.: Chemical composition of $\mathrm{PM}_{2.5}$ and meteorological impact among three years in urban Shanghai, China, J. Clean. Prod., 112, 1302-1311, https://doi.org/10.1016/j.jclepro.2015.04.099, 2016.

Wang, K., Zhang, Y., Nenes, A., and Fountoukis, C.: Implementation of dust emission and chemistry into the Community Multiscale Air Quality modeling system and initial application to an Asian dust storm episode, Atmos. Chem. Phys., 12, 1020910237, https://doi.org/10.5194/acp-12-10209-2012, 2012.

Wang, Y., Zhuang, G., Tang, A., Yuan, H., Sun, Y., Chen, Sh., and Zheng, A.: The ion chemistry and the source of $\mathrm{PM}_{2.5}$ aerosol in Beijing, Atmos. Environ., 39, 3771-3784, https://doi.org/10.1016/j.atmosenv.2005.03.013, 2005.

Wang, Y., Zhuang, G., Zhang, X., Huang, K., Xu, C., Tang, A., Chen, J., and Zheng, A.: The ion chemistry, seasonal cycle, and sources of $\mathrm{PM}_{2.5}$ and TSP aerosol in Shanghai, Atmos. Environ., 40, 2935-2952, https://doi.org/10.1016/j.atmosenv.2005.12.051, 2006.
Wexler, A. S. and Clegg, S. L.: Atmospheric aerosol models for systems including the ions $\mathrm{H}^{+}, \mathrm{NH}_{4}^{+}, \mathrm{Na}^{+}, \mathrm{SO}_{4}^{2-}$, $\mathrm{NO}_{3}^{-}, \mathrm{Cl}^{-}, \mathrm{Br}^{-}$, and $\mathrm{H}_{2} \mathrm{O}$, J. Geophys. Res., 107, 4207, https://doi.org/10.1029/2001JD000451, 2002.

WHO: Health Risks of Particulate Matter from Long-range Transbounday Air Pollution, E88189. European Centre for Environment and Health, WHO Regional Office for Europe, Denmark, 2006a.

WHO: WHO Air quality guidelines for particulate matter, ozone, nitrogen dioxide and sulphur dioxide, Global update 2005, Summary of risk assessment, WHO/SDE/PHE/ OEH/06.02, Geneva, Switzerland, 2006b.

Wonaschutz, A., Demattio, A., Wagner, R., Burkart, J., Zikova, N., Vodicka, P., Ludwig, W., Steiner, G., Schwarz, J., and Hitzenberger, R.: Seasonality of new particle formation in Vienna, Austria - Influence of air mass origin and aerosol chemical composition, Atmos. Environ., 118, 118-126, https://doi.org/10.1016/j.atmosenv.2015.07.035, 2015.

Yao, X. H., Lau, A. P. S., Fang, M., Chan, C. K., and Hu, M.: Size distributions and formation of ionic species in atmospheric particulate pollutants in Beijing, China: 1 - inorganic ions, Atmos. Environ., 37, 2991-3000, https://doi.org/10.1016/S13522310(03)00255-3, 2003.

Zhang, L. M., Gong, S. L., Padro, J., and Barrie, L.: A size segregated particle dry deposition scheme for an atmospheric aerosol module, Atmos. Environ., 35, 549-560, https://doi.org/10.1016/S1352-2310(00)00326-5, 2001.

Zhang, R., Wang, G., Guo, S., Zamora, M. L., Ying, Q., Lin, Y., Wang, W., Hu, M., and Wang, Y.: Formation of urban fine particulate matter, Chem. Rev., 115, 3803-3855, https://doi.org/10.1021/acs.chemrev.5b00067, 2015.

Zhao, M., Wang, S., Tan, J., Hua, Y., Wu, D., and Hao, J.: Variation of urban atmospheric ammonia pollution and its relation with $\mathrm{PM}_{2.5}$ chemical property in winter of Beijing, China, Aerosol Air Qual. Res., 16, 1378-1389, https://doi.org/10.4209/aaqr.2015.12.0699, 2016. 